\title{
Weed-insect pollinator networks as bio-indicators of ecological sustainability in agriculture. A review
}

\author{
Orianne Rollin ${ }^{1,2} \cdot$ Giovanni Benelli $^{3} \cdot$ Stefano Benvenuti $^{4} \cdot$ Axel Decourtye $^{1,2,5}$. \\ Steve D. Wratten ${ }^{6}$ • Angelo Canale ${ }^{3} \cdot$ Nicolas Desneux $^{7}$
}

\begin{abstract}
The intensification of agricultural practices contributes to the decline of many taxa such as insects and wild plants. Weeds are serious competitors for crop production and are thus controlled. Nonetheless, weeds enhance floral diversity in agricultural landscapes. Weeds provide food for insects in exchange for pollination. The stability of mutualistic interactions in pollination networks depends on conservation of insect pollinator and weed communities. Some agricultural practices can destabilize interactions and thus modify the stability of pollination networks. Therefore, more knowledge on weed-insect networks is needed. Here, we review the interactions involved in insect visits to weed flowers in temperate arable lands. Our main findings are that (1) weed pollination
\end{abstract}

Giovanni Benelli

g.benelli@sssup.it; benelli.giovanni@gmail.com

$\triangle$ Nicolas Desneux

nicolas.desneux@sophia.inra.fr

1 French National Institute for Beekeeping and Pollination (ITSAP-Institut de l'abeille), Avignon, France

2 UMT PrADE, Avignon, France

3 Department of Agriculture, Food and Environment, Insect Behaviour Group, University of Pisa, via del Borghetto 80, 56124 Pisa, Italy

4 Department of Agriculture, Food and Environment, Agronomy and Agro-ecosystem Management Section, University of Pisa, via del Borghetto 80, 56124 Pisa, Italy

5 ACTA, 228 route de l'aérodrome, Site Agroparc, 84914 Avignon, France

6 Bio-Protection Research Centre, Lincoln University, PO Box 84, Lincoln 7647, New Zealand

7 INRA, UMR 1355 ISA Institut Sophia Agrobiotech, 400 route des Chappes, BP 167, F-06903 Sophia Antipolis, France by insects has a key role in maintaining weed communities in arable lands; (2) weed-insect pollinator interactions are modulated by the flowers' features and their quality which are attracting insects; (3) most weeds are associated with generalist insect pollinators; and (4) even if weed-pollinator networks are largely mutualistic, some antagonist networks can be observed when deception occurs. We propose three weed-insect pollinator networks as potential bio-indicators to evaluate the ecological sustainability of arable land management strategies in temperate areas: (1) Geometridae and Bombyliidae species visiting Caryophyllaceae, (2) Papilionidae foraging on Apiaceae, and (3) Syrphidae visiting Asteraceae.

Keywords Arthropods · Biodiversity · Pollination · Weed management $\cdot$ Wildflowers

\section{Contents}

1. Introduction

2. Pollination strategies of weeds in temperate arable lands: the key role of insects

3. Insect-pollinated plants: "attract and reward" mechanisms

4. Do generalist insect pollinators serve weeds better? Not always

5. Diversity and stability of weed-insect pollinator networks: a bio-indicator of the arable land health?

6. Agricultural practices affecting the stability of weed-insect pollinator networks

6.1. The spatiotemporal dynamic in agricultural landscapes: the importance of a heterogeneous mosaic

6.2. The key role of the untilled areas for weed-insect pollinator networks

6.3. Reduce external inputs to increase biodiversity

6.4. No tillage: an efficient practice to associate with other environmental strategies 
7. Conclusions

Acknowledgements

References

\section{Introduction}

Agricultural ecosystems are the dominant landscapes throughout Western Europe and worldwide (Robinson and Sutherland 2002; Scheper et al. 2013). Due to the continuous increase of the world human population, "cropland", "arable land", "farmland" or "agricultural land" have considerably increased (Matson et al. 1997; Tscharntke et al. 2005), by conversion of natural and semi-natural areas. These changes have accelerated especially in the post-war period characterized by increased external inputs such as fertilizers and pesticides (Tscharntke et al. 2005). This agricultural intensification had led to a decline of landscape diversity and a loss of biodiversity observed in many taxa, especially for insects and plants (Sotherton 1998; Chamberlain et al. 2000; Benton et al. 2002; Kleijn and Sutherland 2003; Thomas et al. 2004; Tscharntke et al. 2005; Flynn et al. 2009; Brückmann et al. 2010). Weeds are particularly affected due to their contentious relationship with crop production. Indeed, they are historically considered as a serious competitor for crop plants and therefore for crop production (Oerke 2006; Meiss et al. 2008; Fried et al. 2008). However, weeds are a significant part of the floral diversity in agricultural landscapes. They play major functional roles for agricultural ecosystems and their biodiversity and thus have several consequences on ecosystem services, especially pollination (Biesmeijer et al. 2006; Bretagnolle and Gaba 2015). Increasing weed abundance can (i) maintain pollinator populations, (ii) ensure pollination services, (iii) increase honey yields and therefore be a benefit for beekeepers, and (iv) improve the sociocultural value of landscape by ensuring the persistence and survival of wild flora (Bretagnolle and Gaba 2015). For instance, some studies have showed the importance of weeds as food resource for insect pollinators, especially bees (Rollin et al. 2013; Requier et al. 2014).

Weed-insect pollinator interactions are also very important to maintain weeds in agricultural landscapes. Even if weeds are predominantly self-pollinating (Sutherland 2004), windand insect-pollinated species are also typical of agricultural ecosystems (Petanidou and Lamborn 2005). The persistence dynamics of most weed species in arable land are largely driven by insect pollination; the frequency of flower visits by insects is a good parameter for classifying a weed's pollination strategy (Hoffmann 2005; Lunau 2006). There is a growing interest in the gene flow mechanisms among weed species in arable lands. This is due both to agronomic reasons (e.g., herbicide resistance) (Preston and Powles 2002) and to environmental concerns (e.g., pollen transfer between genetically modified crops and hybridizable weeds) (Conner et al.
2003). In addition, several concerns have been raised regarding the decreased plant and pollinator biodiversity in different ecosystems, focusing on the possible relation between the rarefaction of some plants and their dependence on particular insect pollinators (Benvenuti 2004; Gibson et al. 2006; Nicholls and Altieri 2012; Grass et al. 2013). The decline in wild bee diversity has been strongly correlated with the decline in wildflowers (Biesmeijer et al. 2006; Bretagnolle and Gaba 2015 for a recent review).

On this basis, the aims of this review are to (i) examine the key role of insects in the pollination strategies of weeds in temperate arable lands, (ii) highlight the mechanisms involved in insect visits to weed flowers in arable lands, (iii) provide a focus on the ecological importance of generalized interactions in insect pollinator-weed dynamics, (iv) highlight the diversity of weed-insect pollinator interactions and their potential as bio-indicators to evaluate the health of temperate arable lands, and (v) analyze sustainable farming practices designed to partly maintain weed-insect pollinator interactions.

\section{Pollination strategies of weeds in temperate arable lands: the key role of insects}

Not all flowering plants have the same pollination requirements. Plants can use different mechanisms to realize selfpollination, which is pollination of a flower by pollen from the same flower or flower on the same plant (Pesson and Louveaux 1984). In agreement with the time limitation hypothesis, self-pollination is crucial for rapid seed formation (Aarssen 2000). Due to this rapid seed set, arable land weeds can persist despite the vast range of agronomic disturbances (Sutherland 2004). For instance, Amaranthus retroflexus L. (Amaranthaceae) is characterized by unattractive flowers, almost total self-pollination (Brenner et al. 2000), and produces mature seeds just a few weeks after emergence (Costea et al. 2004). This reproductive strategy is an advantage if pollinators are in decline or absent (Barbier 1986). For instance, if cross-pollination by insects does not occur, dandelion (Taraxacum ssp.) and plants of the thistle family (Carthamus ssp.) ensure their reproduction by a mechanical selfpollination within the flower, through contact between the ripe stigma and pollen grains of anthers (Barbier 1986). Other weeds with flowers that are easily recognizable by insects are mainly self-pollinated, for example Convolvulus arvensis L. (Convolvulaceae) (Westwood et al. 1997), Stellaria media (L.) Vill. (Caryophyllaceae) (Verkleij et al. 1980), Portulaca oleracea L. (Portulacaceae) (Zimmerman 1977), and Anagallis arvensis L. (Primulaceae) (Gibbs and Talavera 2001).

However, to prevent self-pollination and inbreeding, many species use cross-pollination which promotes genetic diversity and permits the adaptation of plants to environmental 
disturbances (Barbier 1986; Delaplane and Mayer 2000). The cross-pollination of angiosperms evolved in ancient natural ecosystems, from entomophily to anemophily (Thien 1980), which is likely to reduce the dependence on organisms that are strongly affected by erratic climatic conditions (Bawa 1995). This is supported by rudimental and inefficient nectaries in wind-pollinated species (Culley et al. 2002). Ambophily is regarded as an intermediate transitional state between biotic and/or abiotic pollen movements (Culley et al. 2002) and generates gene flow, allowing the environmental plasticity needed for successful persistence in arable lands. This strategy enables a shift from predominant self-pollination to cross-pollination, as observed in many weeds (Holsinger 1991).

To promote cross-pollination, species have developed selfincompatibility mechanisms (e.g., Papaver rhoeas L. (Papaveraceae) and Ranunculus repens L. (Ranunculaceae)) (Lundqvist 1994; Thomas and Franklin-Tong 2004). Selfincompatible plants are receptive to each other's pollen and cannot develop seeds and fruit if pollen is transferred from anthers of a flower to the stigma of the same flower or different flower on the same plant (Fig. 1) (Barbier 1986). Absolute self-incompatibility is rare. A variable frequency of distribution between self- and cross-pollination is frequently observed, for example Anthemis cotula L. (Asteraceae) (Kay 1971), Raphanus raphanistrum L. (Sampson 1967), and Sinapis arvensis (L.) (Brassicaceae) (Stevens and Kay 1989). In the latter species, the white-yellowish flowers can favor or discourage insect visits. For instance, Pieris rapae L. (Lepidoptera: Pieridae) mainly visits yellow flowers, resulting in a predominance of cross-pollination in these populations (Stanton et al. 1989). In contrast, self-pollination dominates in varieties with white flowers. This phenomenon is not exclusive to Brassicaceae. It is also widespread in many weeds and could be a strategy for maintaining populations with diverse biological characteristics (Clegg and Durbin 2000).

Pollen self-incompatibility is one of the various strategies adopted by plant species to prevent the pollination of different flowers growing on the same plant, especially in the case of individuals with numerous blooms (Di Pasquale and Jacobi 1998). Such pollination, which is pointless in terms of gene flow, is known as geitonogamy. Geitonogamy avoidance

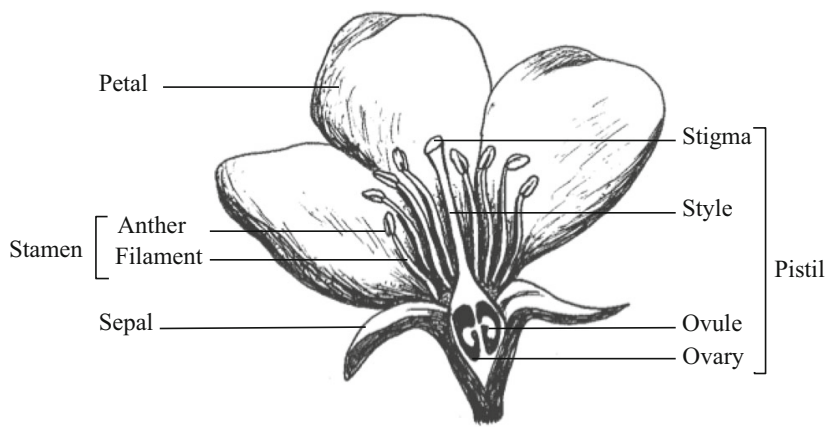

Fig. 1 General morphology of a flower strategies include spatial and/or temporal separation of pollen and stigma (De Jong et al. 1993). Geitonogamy avoidance is advantageous in favoring adaptability to fast-changing environmental conditions (De Jong 2000; Torres et al. 2013). A trade-off between geitonogamy and xenogamy (i.e., cross-pollination) has been observed in andromonoecious and protandrous species, such as Daucus carota L. (Apiaceae) (Koul et al. 1989). In this case, the separation of the male and female phases is complete at the level of the flower and umbel; however, the two phases overlap at the level of the full plant, thus creating conditions for geitonogamy, though insect visits among the umbels of adjacent plants lead to xenogamy. Another interesting feature of this weed is the possible ecological role of the dark central floret of the inflorescence. This peculiar structure may act as a "fly catcher," although its real function is essentially unknown (Lamborn and Ollerton 2000). Other intermediate examples between self-pollination and cross-pollination include Cynoglossum officinale L., Echium vulgare L. (Boraginaceae) (De Jong 2000), and Delphinium spp. (Ranunculaceae) (Ishii and Harder 2006), in which the extremely variable number of flowers results in various levels of geitonogamy. The plants with a greater number of flowers tend to favor both self-pollination and insectmediated cross-pollination, since the pollinators visit flowers of the same plant in sequence. A further diversification of breeding frequency is found in E. vulgare L. (Boraginaceae), in which the protandrous flowers produce more nectar and receive higher rates of visitation during their male than their female phases (Klinkhamer and de Jong 1990; Leiss and Klinkhamer 2005). Of the geitonogamy avoidance strategies, a drastic mechanism is displayed by the dioecious species, in which the separation of individuals into different sexes makes self-fertilization impossible. One example is Silene dioica (L.) Clairv. (Caryophyllaceae), which is visited by Apidae (mainly honey bees and bumblebees), Syrphidae, and Lepidoptera (particularly Pieridae species) (Kay et al. 1984). However, since the invasiveness of this species in arable lands is negligible, compared to monoecious Silene species, the cited strategy may be unsuccessful (Blair and Wolfe 2004). On this basis, dioecy is unlikely to be suitable for the persistence of insect-pollinated weeds in highly disturbed environments.

The predominance of self-fertilization is more widespread in the biotypes of agricultural environments, while outcrossing is widespread in biotypes of less disturbed environments. The disturbance factors of arable lands are likely to be favorable to predominantly self-pollinated biotypes (Hermanutz 1991). This is the case of Datura stramonium L. (Solanaceae), which is pollinated in its original environment by the hawkmoth, Manduca quinquemaculata Haworth (Lepidoptera: Sphingidae), Halictidae, and honey bees, while it is almost autogamous in arable lands (Motten and Antonovics 1992). However, the pollination strategy of some weed species depends on the extent of disturbance in 
their environment. For instance, Solanum ptycanthum Dun. (Solanaceae) has predominantly insect-pollinated biotypes in natural ecosystems and predominantly self-pollinated biotypes in agro-ecosystems (Hermanutz 1991). These biological responses to agronomic disturbances have led to a decrease in nectary function, elongation of the androecium and gynoecium allowing contact between anthers and stigma, thus favoring self-pollination (Motten and Stone 2000). Agricultural disturbance such as soil fertilization tends to minimize the herkogamy of the original genotypes (i.e., different elongation of male and female apparatus), thus encouraging self-pollination. Thus, pollination strategy of weeds could be an indicator of the intensification of arable areas, with more insectpollinated weeds in agricultural landscapes with less intensive practices.

\section{Insect-pollinated plants: "attract and reward" mechanisms}

Hymenoptera, Diptera, Lepidoptera, and Coleoptera are the majority of insects feeding on flowers in temperate regions. Each species feeds on the pollen and/or nectar of a plant species depending on its mouthparts, which have often evolved to enable the insect to feed on solid (e.g., pollen) or liquid (e.g., nectar) (Krenn et al. 2005). Among flower visitors, eusocial bees (e.g., the honey bees (Apis mellifera L.), bumblebees (Bombus spp.)) (Fig. 2) and solitary bees dominate. In Mediterranean arable lands, Andrenidae, Apidae, Colletidae, Halictidae, Megachilidae, and Melittidae are the main species of solitary bees (Bosch et al. 1997; Dicks et al. 2002; Petanidou and Lamborn 2005; Bretagnolle and Gaba 2015). However, some species of the Halictidae (Halictus and Lasioglossum particularly, e.g., Lasioglossum malachurum (Kirby), Lasioglossum pauxillum (Schenck), Halictus rubicundus (Christ)) are eusocial (Michener 2007) and can be locally dominant and abundant wild bee species (Rollin et al. 2015). The flower reward consists of nectar, pollen, or both (Table 1). Pollen grains have very different tridimensional structure according to their botanical family (Fig. 3), which facilitates their adherence to various parts of the insect body, thus enabling transportation, and/or is packed in pollen baskets on the legs of several Apidae (e.g., the corbiculae of honey bees and bumblebees). However, workers of social species (e.g., honey bees and bumblebees) rarely collect pollen and nectar simultaneously. They usually direct their visits to flower species with a predominance of one or the other reward (Tepedino and Parker 1982; Rasheed and Harder 1997). Natural ecosystems have an abundance of wildflowers which frequently offer nectar production as a reward. On the other hand, agro-ecosystems such as arable lands often have a predominance of species that are poor in nectar, and insects are rewarded with pollen. For instance, the common

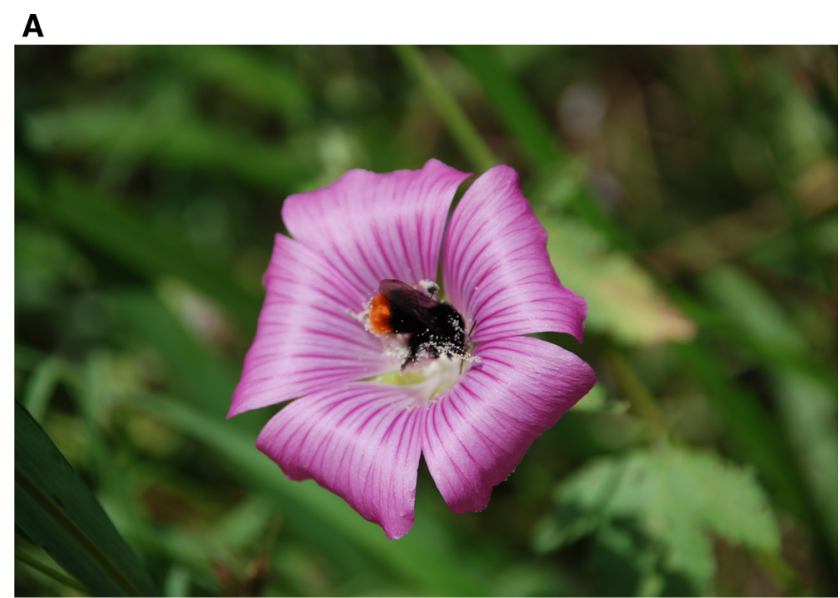

B

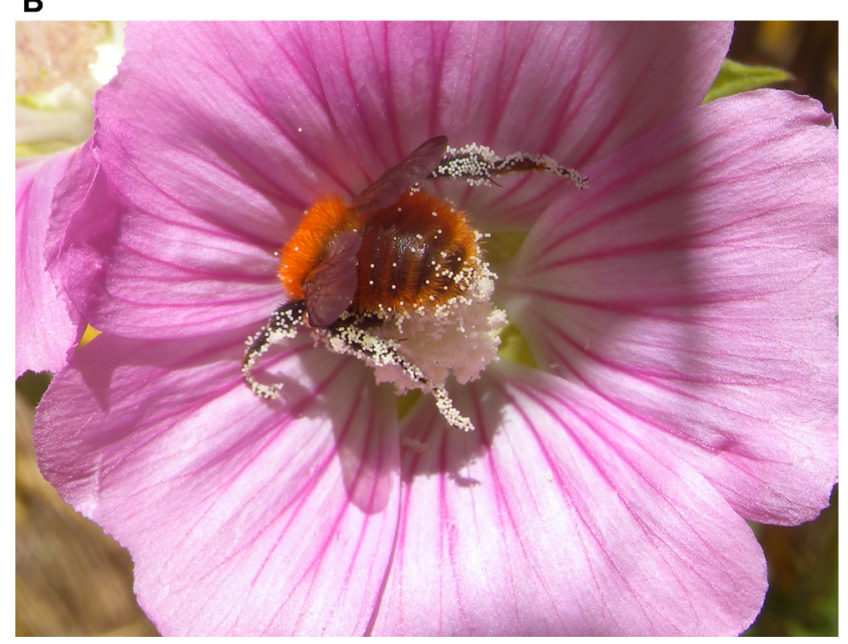

Fig. 2 Weeds such as the annual tree mallow, Lavatera punctata All. (Malvales: Malvaceae), are abundant sources of pollen and nectar for many insects, including bumblebees (Hymenoptera: Apidae), such as a the red-tailed bumblebee, Bombus lapidarius (L.), and b the common carder-bee, Bombus pascuorum (Scopoli)

poppy, P. rhoeas L. (Papaveraceae), a completely selfincompatible species, has no nectaries, and pollen is the only reward for visiting insects (Thomas and Franklin-Tong 2004). In intensive cereal landscape, poppies can account for up to $60 \%$ of pollen resources for honey bees during late spring, in June (Odoux et al. 2012; Requier et al. 2014).

Although weeds with brightly colored flowers are frequently visited by insects, even species with duller flowers can provide key food floral sources, especially when few other plants are in flower (e.g., early spring) (Levin and Anderson 1970; Petanidou and Vokou 1993; Dafni 1996; Odoux et al. 2012; Rollin et al. 2013; Benelli et al. 2014; Canale et al. 2014; Requier et al. 2014). In late summer, insect pollinators can be observed on the most common weed species in seminatural habitats, such as many Asteraceae (e.g., Aster squamatus (Sprengel) Hieron, Conyza canadensis (L.) Cronq., Senecio vulgaris L., Sonchus spp., and Xanthium 


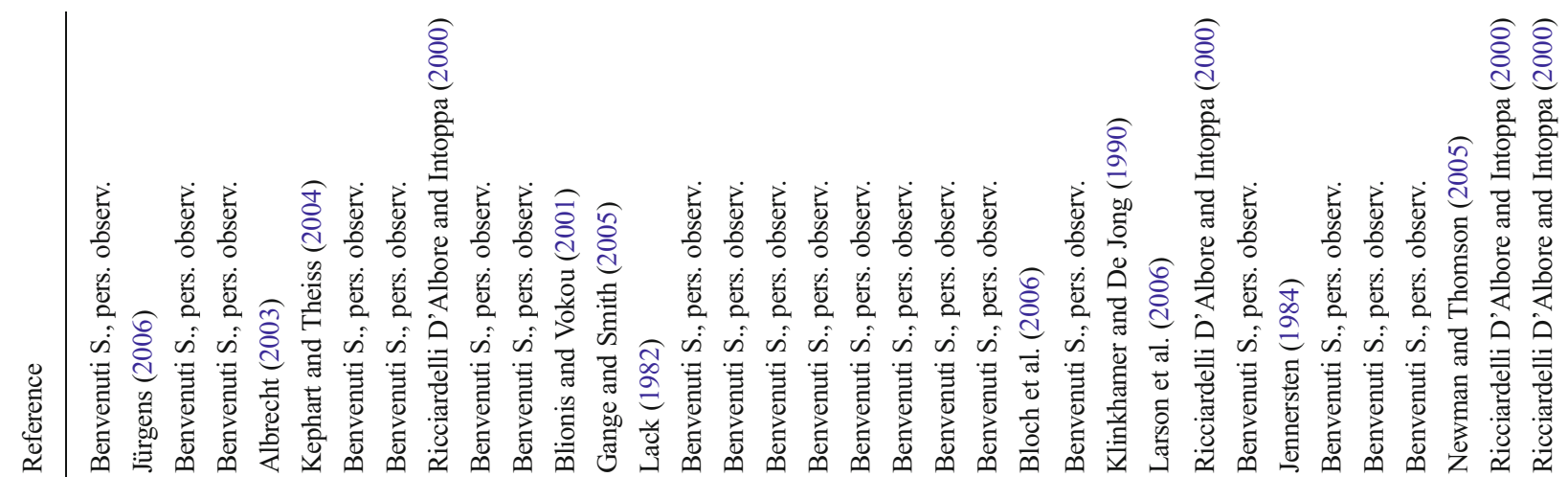

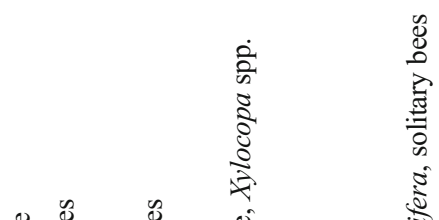

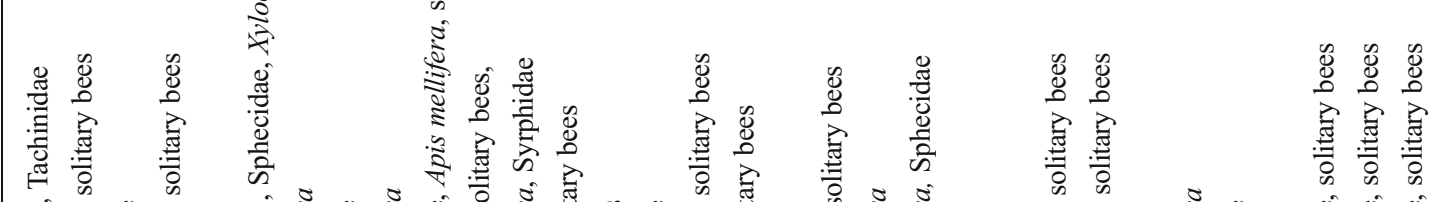

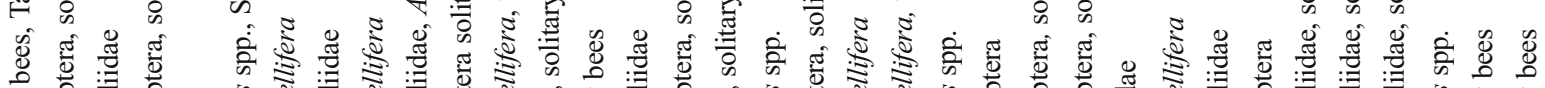

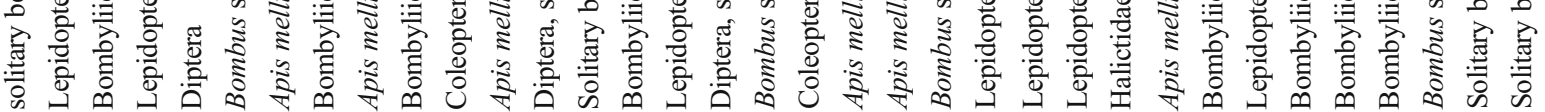

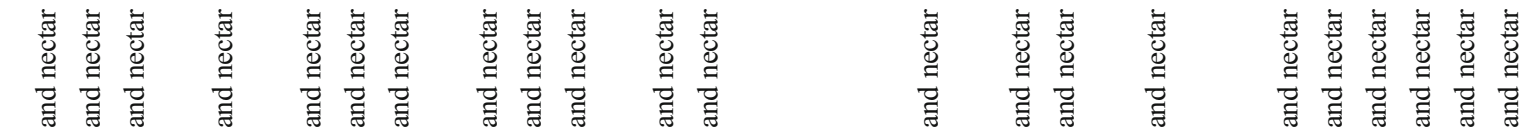

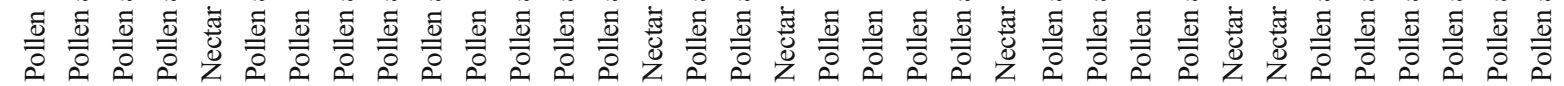

घु

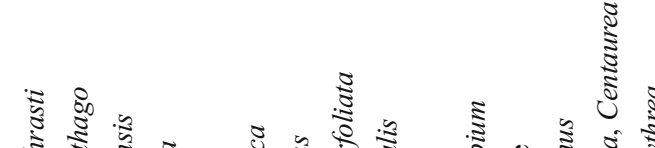<smiles>C1CCCCC1</smiles>

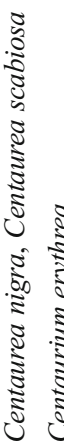

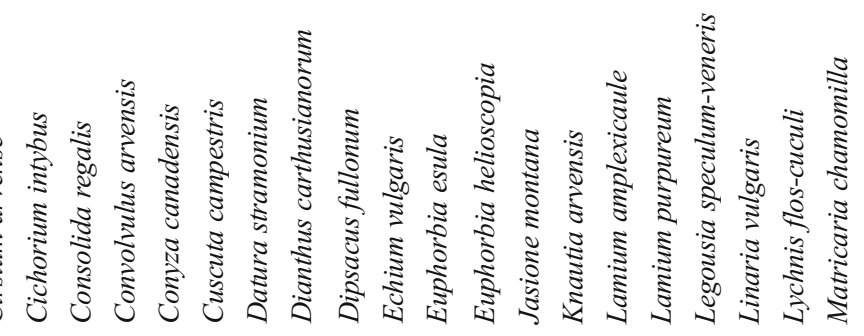




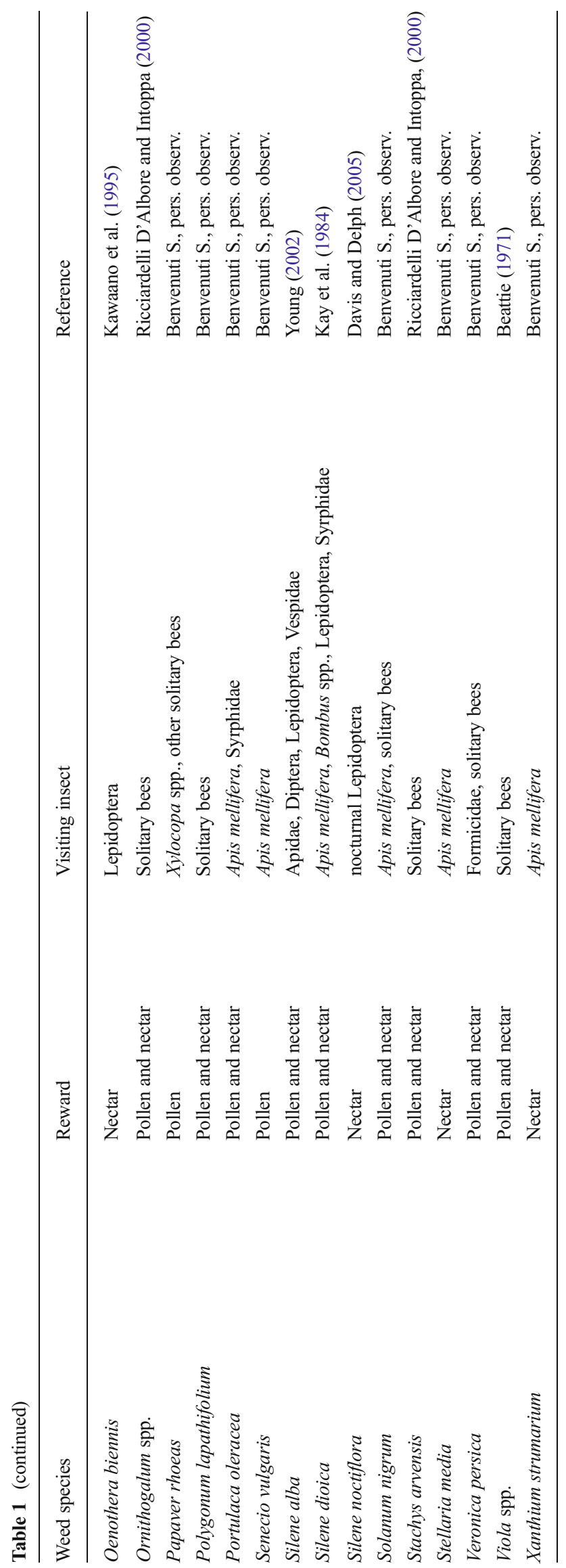

strumarium L.) (Rollin 2013). Solitary bees and bumblebees can be observed also on other weeds with inconspicuous flowers, such as Polygonum lapathifolium L., Polygonum aviculare L. (Polygonaceae), Cuscuta campestris Yuncker (Convolvulaceae), P. oleracea L. (Portulacaceae), S. media (L.) Vill. (Caryophyllaceae), and Abutilon theophrasti Medik. (Malvaceae), or on weeds with gaudy but usually self-pollinated flowers, such as C. arvensis L., Calystegia saepium (L.) R. Br. (Convolvulaceae) (Westwood et al. 1997), and D. stramonium L. (Solanaceae) (Motten and Antonovics 1992).

Of the insects visiting weed flowers, an underestimated role is played by many Diptera, including Syrphidae, Bombyliidae, Tachinidae, and Sarcophagidae (Larson et al. 2001; Katzourakis et al. 2001; Howlett et al. 2009; Pisciotta et al. 2011). Although pollen feeding is widespread in Diptera, no species with mouthpart structures exclusively used for pollen feeding have been identified (Gilbert and Jervis 1998). It is interesting to note that the only adaptations to pollen feeding are the labellar food furrows described for Syrphidae (Schuhmacher and Hoffmann 1982) but a clear adaptational value of the food furrows is questionable, since they are lacking in many pollen feeders (Krenn et al. 2005). Because of the long proboscis of Syrphinae and Eristalinae, adults of these Syrphidae are usually considered visitors of a wide range of flowers, where they feed mostly on nectar (Pesson 1984). These Diptera can also feed on pollen grains, especially of Graminaceae and Oleaceae (Canale and Loni 2010), which must first be humidified with saliva (Gilbert 1985). Foraging visits by Bombyliidae have been noted on flowers that are difficult to reach for other insects due to their small and elongated floral calyx, such as Gentianaceae (e.g., Centaurium erythraea Rafn. and Blackstonia perfoliata (L.) Huds.), Campanulaceae (e.g., Legousia speculum-veneris (L.) Chaix and Jasione montana L.), Lamiaceae (e.g., Lamium purpureum L. and Lamium amplexicaule L.), and Primulaceae (e.g., A. arvensis L. and Anagallis foemina Mill.). The role of Bombyliidae as pollinators is likely to be minimal. Indeed, bee flies usually insert their proboscis into flowers, but their tongues are so long and slender that their heads are not inserted into the floral mouth, thus probably only a few pollen grains are removed (Krenn et al. 2005). The small role of bee flies as pollinators may also be due to their foraging behavior. Bee flies are rarely observed sitting or walking on top of inflorescences, instead they usually hover in close proximity to flowers, thus reducing the chances of pollen grains adhering to their bodies (Canale et al. 2014, 2015) (Fig. 4).

Lepidoptera also have a long proboscis that enables them to visit flowers with nectaries hidden in an elongated calyx (Table 2). Such insects include Lycaenidae, Pieridae and Sphingidae, Papilionidae, Nymphalidae, and Satyridae. Visits are frequent on flower species whose flowers have a particular shape, such as Dipsaceae (Knautia arvensis (L.) 
Fig. 3 Scanning electron microscopy of pollen grains of $\mathbf{a}$ Bellis perennis L. (Asteraceae), b Taraxacum sp. (Asteraceae), c Geranium molle L.

(Geraniaceae), d Capsella bursapastoris (L.) Medik.

(Brassicaceae), e Papaver rhoeas

L. (Papaveraceae), and $\mathbf{f}$ Trifolium pratense L. (Fabaceae). C I. Bornard (Lab. Microscopie, Pathologie Végétale, INRA Avignon, France) and R. Chifflet and B. Vaissière (UMR Abeilles \& Environnement, INRA Avignon \& Univ. Avignon, France)
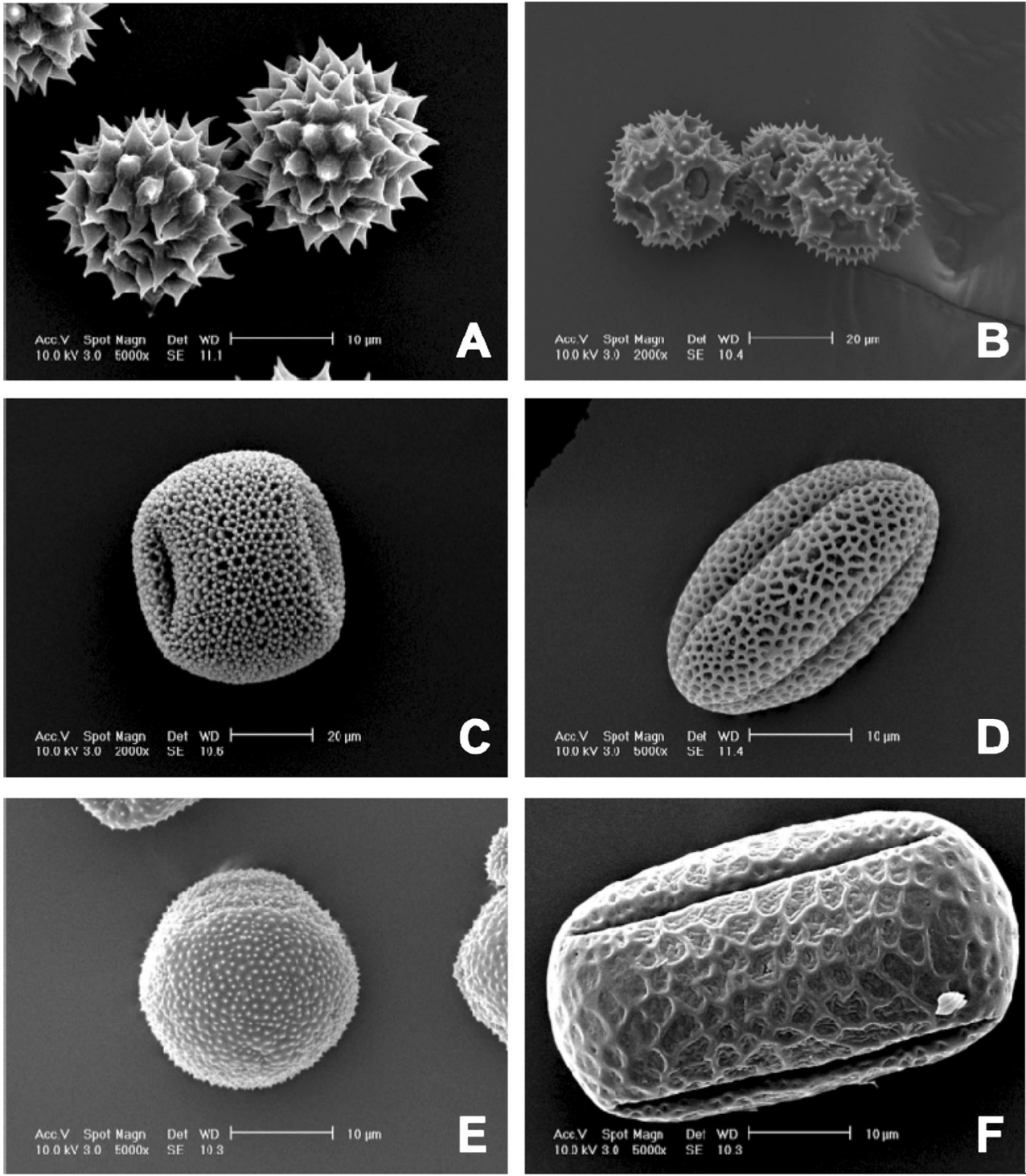

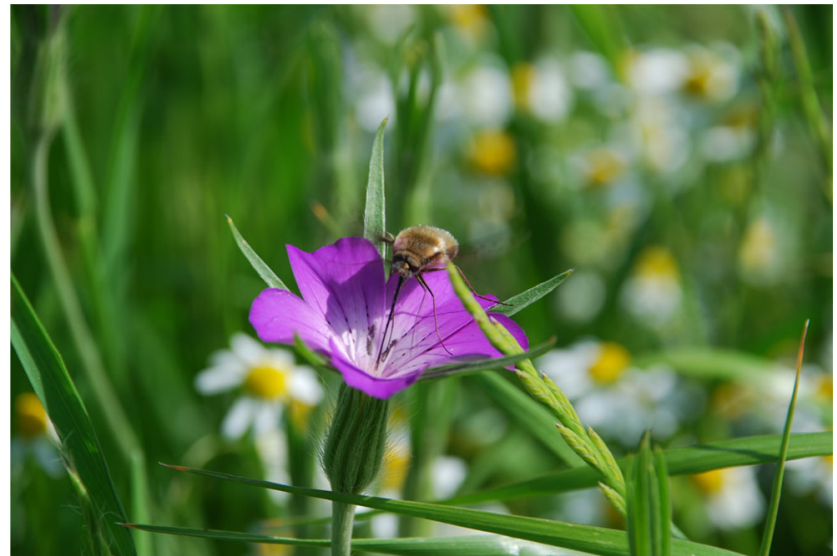

Fig. 4 Bee flies (Diptera: Bombyliidae) hover in close proximity to flowers, thus reducing the chances of pollen grains adhering to their bodies: here, a flower of Agrostemma githago L. (Caryophyllales: Caryophyllaceae) visited by Bombylius fulvescens Wiedemann
Coulter and Dipsacus fullonum L.) and Caryophyllaceae (Agrostemma githago L. and Silene spp.). Overall, the pollen transport by butterflies seems to be less efficient than by Hymenoptera (Jennersten 1984). Particular mechanisms may enhance it. For instance, some weeds (e.g., Lychnis flos-cuculi L. (Caryophyllales: Caryophyllaceae)) are slender with flowers at the apex. During foraging, the weight of the butterfly (e.g., Pieridae, such as Gonepteryx rhamni (L.)) bends the stem so that the flower opening points downwards (Fig. 5). The insect movements thus enable the pollen to be detached from the floral parts and to adhere to the insect's body (Benelli G., pers. observ.).

Coleoptera and Thysanoptera are visiting weed flowers but appear to act pollen predators rather than potential pollinators because their larvae exhibit parasitic behavior, feeding on pollen grains of fresh flowers which are still attached to the plant (Sakai 2002). Similarly, poor efficiency is seen in ants 
Table 2 Some examples of Lepidoptera species foraging on weed flowers

\begin{tabular}{|c|c|c|}
\hline Weed & Lepidoptera & Reference \\
\hline Amaranthus spp., Chenopodium spp. & Pholisora catullus & Shapiro (2002) \\
\hline Apiaceae & Papilio machaon & Wiklund (1981) \\
\hline Aristolochia spp. & Parnalius polyxena & Novák and Severa (1980) \\
\hline Artemisia vulgaris & Pyrgus serratulae & Novák and Severa (1980) \\
\hline Asteraceae, Malvaceae & Vanessa cardui & Shapiro (2002) \\
\hline Avena fatua & Cercyonis pegala & Shapiro (2002) \\
\hline Bidens pilosa & Nathalis iole & Shapiro (2002) \\
\hline Brassica nigra & Pontia beckerii & Shapiro (2002) \\
\hline Brassicaceae & $\begin{array}{l}\text { Anthocharis sara } \\
\text { Euchloe ausonides } \\
\text { Pieris rapae } \\
\text { Pontia protodice }\end{array}$ & Shapiro (2002) \\
\hline Cardamine spp., Nasturtium spp. & Anthocharis cardamines & Novák and Severa (1980) \\
\hline Caryophyllaceae & Euphyia biangulata & Novák and Severa (1980) \\
\hline Centaurea spp., Plantago spp. & Melitaea didyma & Novák and Severa (1980) \\
\hline Chenopodium album & Brephidium exilis & Shapiro (2002) \\
\hline Centaurea solstitialis, Cirsium spp. & Phycioides mylitta & Shapiro (2002) \\
\hline Centaurea spp., Cirsium spp. & Thymelicus sylvestris & Novák and Severa (1980) \\
\hline Echium vulgare & Ethmia terminella & Novák and Severa (1980) \\
\hline \multirow[t]{2}{*}{ Galium spp. } & Ryparia purpurata & Novák and Severa (1980) \\
\hline & Macroglossum stellatarum & Novák and Severa (1980) \\
\hline \multirow[t]{2}{*}{ Graminaceae } & Brintesia circe & Novák and Severa (1980) \\
\hline & Lerodea eufala & Shapiro (2002) \\
\hline Hypericum spp. & Deilephila elpenor & Novák and Severa (1980) \\
\hline Lamiaceae & Perizoma alchemillata & Novák and Severa (1980) \\
\hline Lythrum spp., Epilobium spp. & Hyles vespertilio & Novák and Severa (1980) \\
\hline Malva sylvestris, Alcea rosea & Heliopetes ericetorum & Shapiro (2002) \\
\hline Malvaceae, Chenopodium album & Pyrgus communis & Shapiro (2002) \\
\hline Malvaceae, Papilionaceae & Strymon melinus & Shapiro (2002) \\
\hline Malvaceae, Urticaceae & Vanessa annabella & Shapiro (2002) \\
\hline Melilotus officinalis, Melilotus alba & Colias eurytheme & Shapiro (2002) \\
\hline Papilionaceae & Cyaniris semiargus & Novák and Severa (1980) \\
\hline Plantago lanceolata, Plantago major & Euphydryas editha & Shapiro (2002) \\
\hline Polygonaceae & Lycaena phlaeas & Novák and Severa (1980) \\
\hline Polygonum persicaria & Lycaena helloides & Shapiro (2002) \\
\hline Rumex crispus & Lycaena xanthoides & Shapiro (2002) \\
\hline Rumex spp. & Lycaena cupreus & Shapiro (2002) \\
\hline Scrophulariaceae & Junonia coenia & Shapiro (2002) \\
\hline Silene spp., Lychnis spp. & Hadena rivularis & Novák and Severa (1980) \\
\hline Sonchus oleraceus & Helicoverpa armigera & Gu et al. (2001) \\
\hline Urtica spp. & Aglais urticae & Novák and Severa (1980) \\
\hline Veronica spp. & Stenoptilia pterodactyla & Novák and Severa (1980) \\
\hline Viola spp. & Argynnis paphia & Novák and Severa (1980) \\
\hline
\end{tabular}

(Hymenoptera: Formicidae), despite their being flower visitors of many species (Bosch et al. 1997). This appears to be due to low pollen germination after ant contact (Beattie et al. 1984). In addition, their lack of hairs, potentially useful as pollen carriers, and their limited plant-to-plant movement suggest that they are only occasional pollinators.

Lastly, ants may negatively affect plant fitness by reducing the intensity of pollinator visits (Junker et al. 2006). Ants' 


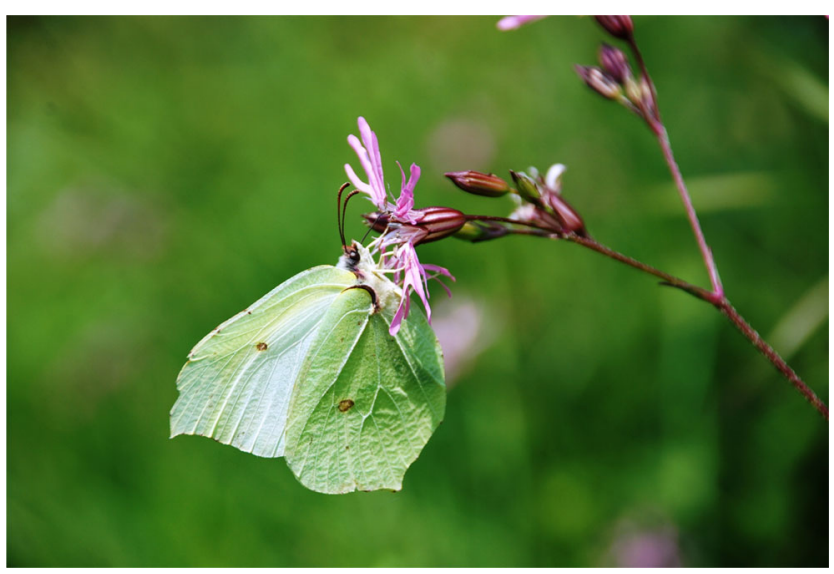

Fig. 5 Some weeds, such as Lychnis flos-cuculi L. (Caryophyllales: Caryophyllaceae), are slender with flowers at the apex. During foraging, the weight of the butterfly (here, a Pieridae, Gonepteryx rhamni (L.)) bends the stem so that the flower opening points downwards. The insect movements thus enable the pollen to be detached from the floral parts and to adhere to the insect's body

activity decreased frequency and duration of pollinator visits by direct attacks or indirect effects due to presence of chemical signals. Nectar robbers that extract nectar through a pierced corolla tube, avoiding contact with anthers and stigmas, are also poor pollinators. A good example is Bombus occidentalis Greene (Hymenoptera: Apidae) which visit Linaria vulgaris Mill. (Scrophulariaceae) to collect nectar, poking holes in the corolla without penetrating inside (Maloof and Inouye 2000; Newman and Thomson 2005).

\section{Do generalist insect pollinators serve weeds better? Not always}

It is widely recognized that the lack of specialization regarding pollinator-plant relationship in common weeds is due to their persistence in time and space (Rodger et al. 2010). The evolutionary trend from generalization to specialization noted in natural ecosystems (Johnson and Steiner 2000) probably does not match the requirements of weeds that grow in arable lands. In these agro-ecosystems, de-specialization seems to be of pivotal importance for insects visiting weed flowers (Huang 2006). Indeed, de-specialization implies a lower risk of pollinator absence due to disturbance (Desneux et al. 2007). Thus, while specialization leads to optimal interaction in a particular ecological niche, it may be a disadvantage when climatic and agronomic conditions impair the appropriate functioning of the insect-weed relationships. Therefore, the specialization occurring among given weeds and insect pollinators could explain their rarity (Sutcliffe and Kay 2000). For instance, the extensive application of pesticides, which is a typical feature of conventional agricultural systems, strongly interferes with the fragile mechanisms that involve rigid insect-flora interactions.
Predominantly, insect-pollinated species have different degrees of specialization depending on the insects involved (Aigner 2001; Shuttleworth and Johnson 2008). Therefore, features such as floral color and symmetry play a key role in plant-pollinator systems (Giurfa et al. 1999; Cooley et al. 2008). Zygomorphic flowers, such as Consolida regalis Gray (Ranunculaceae), E. vulgare L. (Boraginaceae), L. amplexicaule L., and Stachys arvensis (Lamiaceae), are visited mainly by specialized long-tongued bees (e.g., Anthophoridae, Apidae, Melittidae and Megachilidae). This could be due to the particular position of the nectaries (Nilson 1998). A higher number of species visit actinomorphic flowers. For instance, many Asteraceae (e.g., Centaurea cyanus L., Coleostephus myconis (L.) Rchb. f., and Cirsium arvense (L.) Scop.) are visited by a huge number of unspecialized visitors, such as short-tongued bees (e.g., Andrenidae, Colletidae, and Halictidae) and Diptera. R. raphanistrum L. (Brassicaceae) also exhibits the typical floral traits of generalized pollination, such as upright, radially symmetric flowers and exposed reproductive organs (Fenster et al. 2004). Lastly, some insect visits appear limited to a restricted botanical group, as observed for some wild bees (referred to as monolectic or oligolectic (specialists)), which tend to visit a small number of plant families, or genera for pollen (Michener 2007). Polylectic bee species (honey bee, bumblebees) have a generalist foraging behavior, i.e they are, less selective in their choice of flower. In intensive cereal farming systems, a clear segregation pattern in the use of floral resources was found between honey bees and wild bees, with the former being tightly associated with mass-flowering crops (oilseed rape, sunflower) and the latter with semi-natural habitats, grasslands, and grassy strips (Rollin et al. 2013). Bumblebees had an intermediate strategy and were found in both oilseed and semi-natural habitats.

The most frequent insects on flowers of a given weed are not necessarily the most efficient pollinators. Indeed, the efficiency of insects as pollinators, especially bees, depends on many factors concerning pollen transport and deposit, such as the particular morphology of the insect body parts (e.g., pollen baskets or hairs), pollen moistening, flower structure or movement patterns of insect visitors (e.g., the speed of insects while handling flowers, species specificity) (Michener 2007). For bees, scopal hairs may show further modification in their density and plumosity in relation to the size and structure of the pollen grains. For example, bee species that frequently collect pollen from Boraginaceae (e.g., Colletes nasutus, Andrena nasuta) have hooked hairs to pull pollen away from anthers located deep in a small corolla (Michener 2007). The use of nectar or oil to moisten pollen loads (e.g., such as Panurginae and Mellitidae with sparse scopae, or Apidae with hind tibial corbiculae) permits considerable flexibility in sizes of pollen grains that may be collected (Thorp 1979). However, moistened pollen is less available for pollination than uncompacted 
dry pollen (Michener 2007) and decreases the pollination efficiency of bee species. The rapid visits performed by longtongued bees may result in reduced pollen transport (Fenster et al. 2004). However, the electrostatic forces occurring on pollen can guarantee adhesion to the insect, even if it is lacking in hairy structures (Armbruster 2001). Some floral features enhance the pollen transfer during insect visits. A good example is the small hairs on the keel petal of the corolla (i.e., pollen traps): when the flower wilts, the stigma droops down and meets these hairs. Pollen morphology could also modify efficiency of pollen collection (Fig. 3). For example, the length of the spines on cotton pollen physically interfered with the pollen-aggregating process used by Apidae bees (e.g., honey bees, Vaissière and Vinson 1994). Foraging efficiency depends on matching between corolla depth and proboscis length. Foraging rates of bumblebee with long proboscis, even if they are able to utilize a wide variety of corolla depths, are less efficient on plants with short corollas than short-tongued bumblebees (Brian 1957; Ranta and Lundberg 1980; Graham and Jones 1996). This highlights the importance of the evolution of floral characters to facilitate insect landing and improve pollination efficiency (Nyman 1993). In addition, the relation between flower morphology and self- or cross-pollination has also been confirmed in other species (Kalisz et al. 1999). For instance, self-fertilization in Mimulus guttatus DC. (Scrophulariaceae) is affected by the morphology of the lower corolla lip (Arathi and Kelly 2004).

The foraging activity and the specialization are strongly linked to the relationship between the flowering phenology and the biological traits of visiting insects (Westrich 1989; Fenner 1998; Tylianakis et al. 2005; Michener 2007; Mader et al. 2011). Unlike social bees who are active foragers during many months, adults of many solitary bees are active only for a short season. Thus, they can be specialized on a plant which is in bloom at the same time as their adult flight activity period (Michener 2007; Kirk and Howes 2012). The earliest springflying species (e.g., many mining bees such as Andrena chrysoceles, Anthophora plumipes, Osmia rufa with adult flight activity from March to May-June) forage the earliest flowering plants (e.g., Geranium ssp., Lamium ssp.) (Kirk and Howes 2012). On the other hand, the ivy bee (Colletes hederae) is active late in the year (from the end of August for males and from beginning September for females). His emergence coincides with flowering ivy (Hedera helix L.), his main food plant both for pollen and nectar (Michener 2007; Kirk and Howes 2012). For weeds flowering in cool periods, the potential pollinators are represented by insects that can function even at low temperatures, as in the case of earlyflowering Amaryllidaceae which are pollinated by coldtolerant Andrenidae (Herrera 1995). The role of temperature as a limiting factor is confirmed by Campanulaceae which receive fewer pollinator visits as the altitude increases (Blionis and Vokou 2001). In addition, insect pollinators tend to favor peak or early flowerings, while pre-dispersal seed predators tend to favor off-peak or later flowerings (Elzinga et al. 2007). An interesting example of the mutualistic specialization of weed-insect pollinators is Silene noctiflora L. (Caryophyllaceae) with nocturnal moths (Lepidoptera). This gynomonoecious plant has hermaphroditic, pistillate flowers that only open during the night and are pollinated exclusively by nocturnal moths (Davis and Delph 2005). Similarly, Silene alba (Miller) Krause opens its flowers at the end of the day, thereby allowing pollination both by diurnal (e.g., Apidae, Vespidae, Diptera, Syrphidae, and Bombyliidae) and nocturnal visitors (e.g., Noctuidae and Sphingidae) (Young 2002). This "mixed" system is also characteristic of several weeds belonging to Caryophyllaceae (e.g., genera Agrostemma, Saponaria, Dianthus, and Vaccaria) (Jürgens 2006).

Insect visitor-plant specializations do depend not only on flower traits and flowering phenology (Andersson 2008) but also on nectar composition, in terms of sugars and amino acids, viscosity, and the nectar secretion rate (Corbet 2003). It has been hypothesized that some specialist nectarivores can assimilate sucrose, whereas opportunistic nectar feeders digest only simple hexoses (Dupont et al. 2004). Sugar concentration is a key factor in nectar selection by nectar feeders. Indeed, insect pollinators using viscous dipping, such as solitary and social bees, obtain nectar containing higher sugar concentrations (52\%) than those using a suction method (33\%), like butterflies or hummingbirds (Kim et al. 2011). Moreover, honey bees show strong preferences for warmer and less viscous nectar due to faster ingestion and reduced thermoregulation costs, independently of changes in sugar concentration (Nicolson et al. 2013). Amino acids played a key role in attractiveness to insect pollinators. Different amino acids elicit different responses in insect gustative receptors (Gardener and Gillman 2002). For instance, the adult Lepidoptera's diet is based exclusively on nectar. Thus, they are attracted to flowers rich with amino acids, especially female butterflies (Alm et al. 1990; Rusterholz and Erhardt 2000; Gardener and Gillman 2002). Honey bees can also alter their feeding selection in response to amino acids present in nectar. They prefer nectars enriched with some amino acids such as proline or glycine than other enriched with alanine and serine (Alm et al. 1990; Bertazzini et al. 2010). The predominance of phenylalanine and/or gamma-aminobutyric acid attracts long-tongued bees and hoverflies, whereas asparagine and tryptophan seem repellent to these insects (Petanidou et al. 2006). The amino acid concentration in nectar is not exclusively a function of the weed's genotype. It can also be affected by agronomic techniques. For instance, nitrogen fertilization increases nectar amino acid concentration in $A$. githago L. (Caryophyllaceae) (Gardener and Gillman 2001). Arbuscular mycorrhizal fungi can likewise increase the number of flower visitors (mainly Diptera and Hymenoptera) in C. cyanus L. (Asteraceae) (Gange and Smith 2005). Lastly, the ecological significance 
of the toxic nectar secreted for example by some weeds (e.g., Cuscuta spp. (Convolvulaceae), Euphorbia spp. (Euphorbiaceae), and Solanum nigrum L. (Solanaceae)) is poorly understood. Nectar alkaloids may be protective agents against generalized flower visitors like Lepidoptera, while favoring bees, which are both more oligotrophic and less susceptible to alkaloids than Lepidoptera (Rhoades and Bergdahl 1981; Baker and Baker 1983; Adler 2000). However, other hypotheses on the ecological context of toxic nectar have been discussed, which has been linked to the costs of plant defence in terms of pollination services (Gegear et al. 2007). Although the alkaloids in the floral nectar tend to reduce visitation by bumblebees, the magnitude of the effect is likely to depend on the availability and nectar properties of alternative flowers.

The attraction of visiting insects is also linked to the mechanisms involved in flower recognition. The recognition of appropriate flowers is crucial to prevent wasting energy (Fenster et al. 2004). Thus, flower shape and color play a key role in routing insect foraging flights (Menzel and Shmida 1993). Many Brassicaceae species reflect ultraviolet radiation to attract insect pollinators (Yoshioka et al. 2005). Some flower colors are correlated with particular pollinator species, although this cannot be generalized since data from different environments do not necessarily lead to the same conclusion (Petanidou and Lamborn 2005). Specialist bumblebees prefer purple flowers, which seems to confirm the "pollination syndrome" theory (Nakano and Washitani 2003). The "pollination syndrome" is the hypothetical correlative relationship between floral characters (e.g., shapes, structures, colors) and the forager traits of the animal groups serving as flower pollinators. Flower recognition by insects can be facilitated by color patterns. The "search images" system possessed by insects (Goulson 2000) can be aided by characteristic black spots at the base of the petal, functioning as a "nectar guide" (Johnson and Dafni 1998), as observed in P. rhoeas (Papaveraceae). Bright and gaudy colors are not always required to oligotrophic and less susceptible flower visitors. Some Euphorbiaceae have pale green flowers. However, they are frequently visited by insects (e.g., Euphorbia esula L. and Euphorbia helioscopia L. (Euphorbiaceae)) (Larson et al. 2006; Benvenuti S., pers. observ.). Recently, it has been noted that the pale color of flowers, often defined as a feature to attract pollinators, is not maintained by pollen-mediated selection but by another mechanisms. The value of combining experimental pollen supplementation and reductions can be correlated with variation of floral traits, especially in species where compatible pollen receipt is difficult to measure (Campbell and Bischoff 2013). With regard to olfactory and tactile cues, a mechanism for identification and recognition of flowers also consists in the production and emission of volatile compounds, mainly terpenoids and benzenoids (van Schie et al. 2006). The two dominant components of the fragrance of Cirsium species
(Asteraceae), benzaldehyde and phenylacetaldehyde, attract several orders of generalist insect pollinators (Theis 2006). Fragrance of their flowers is emitted in dynamic patterns that maximize pollinator attraction (Theis et al. 2007). For instance, generalist pollinators, such as oligolectic bees, often show innate sensory preferences for particular floral scent compounds of their host plant (Wright and Schiestl 2009; Dötterl et al. 2011; Burger et al. 2011). In addition an insect's preferences for particular flower cues mean that it can actively identify new flower-borne physical and olfactory stimuli (Arak and Enquist 1993; Naug and Arathi 2007). Insects also have learning abilities to associate chemical signals to their food sources (Dukas 2008). Diptera, Lepidoptera, and Hymenoptera are the best examples of olfactory learning in insects (Wright and Schiestl 2009). Finally, using of olfactory signals provides more fitness advantages to both plant and pollinator than using of visual signals alone (Wright and Schiestl 2009).

\section{Diversity and stability of weed-insect pollinator networks: a bio-indicator of the arable land health?}

Plant-insect pollinator networks are largely mutualistic networks, providing benefits for both plants and insects (Waser and Ollerton 2006). Flowers offer rewards like nectar and/or pollen to their pollinators which in turn pollinate them. On their bodies, they transport pollen grains from one flower to another (of the same species). Insects can learn which flowers provide rewards and then search for more individuals of the same species to get more of it (Sauvion et al. 2013). However, there are antagonistic interactions between pollinators and wildflowers. Some flowers deceive the insect visitors by not providing any reward, while some insects exploit the plants' resources without providing pollination (Waser and Ollerton 2006). Deceptive flowers can use olfactory, visual, or sexual cues to attract pollinators. This principle is especially common in orchids. One third of orchid species use deception to be pollinated, which represents $87 \%$ of the known examples of deceptive pollination (Sauvion et al. 2013). For instance, Cypripedium calceolus L. emits a scent that attracts some honey bee species (e.g., Andrena, Lasioglossum, and Halictus genera; van der Cingel 2001). In a similar manner, Anacamptis pyramidalis L. does not produce nectar but their inflorescence resembles that of nectar-producing species very closely regarding size, shape, and color (Sauvion et al. 2013). Cases of sexual mimicry can be found in the genus Ophrys: Their labellum imitates female insects regarding size, shape, color, and sometimes even hairiness so well that it successfully attracts the respective males (e.g., Ophrys sulcata with Andrena flavipes, Ophrys passionis with Andrena carbonaria; Sauvion et al. 2013). Deceiving insect pollinators, on the other hand, can obtain nectar from flowers but 
withhold pollination. A number of plants possess floral structures that only grant access to certain insect visitors. Hummingbirds, ants, wasps, and bees, however, may be able to collect the reward, which is usually nectar, without touching the plant's reproductive organs (Rust 1979; Roubik 1982; Galen 1983; Scott et al. 1993; Stout et al. 2000). Nectar production comes with a significant cost for plants: it may demand up to $37 \%$ of their available energy (Southwick 1984). Moreover, if wildflowers are cheated out of their nectar, this may considerably impair their ability to produce seeds (Blandfordia nobilis; Pyke 1991). By lessening pollination success, nectar robbing could significantly reduce the fitness of wild plants.

Mutualistic pollination networks are key ecological processes in many terrestrial ecosystems. The stability of these networks depends on some structural properties, such as number of species, number of links between species, and specialization of the network (Vázquez et al. 2009). Plant-pollinator networks have a strong variability (on average four times more pollinator species than plant species; Vázquez et al. 2009). Interspecific interaction between a plant and a pollinator is called a link (Jordano 1987). Species are characterized by their degree, that is the number of links with other species (Jordano et al. 2003; Bascompte et al. 2006). Most of the species have a low degree: they are connected with few other species (Vázquez et al. 2009). For example, a pollinator is considered as specialized if it is connected to just one plant species. However, being a generalist is the more frequent behavior in plant-pollinator networks (Memmott 1999). The majority of plants is pollinated by several pollinators. In the same way, insect pollinators visit several plant species, even if they are from the same genus or family. Specialization can be measured as the specific or network level (Blüthgen et al. 2006). The second is used to study the stability of the network in the ecosystem which can be affected by many environmental factors.

In arable fields particularly, a large number of insectpollinated weeds are rare or in decline. Some examples are A. githago L. (Caryophyllaceae), C. cyanus L. (Asteraceae), Papaver argemone L. (Papaveraceae), Ranunculus arvensis L. (Ranunculaceae) (Chancellor 1977), Glebionis segetum L. Fourr. (Asteraceae), Legousia hybrid (Campanulaceae), Matricaria chamomilla L. (Asteraceae), S. alba, Viola arvensis Murray (Violaceae) (Chancellor 1986), C. regalis L. (Ranunculaceae), L. amplexicaule L. (Lamiaceae), S. noctiflora L. (Caryophyllaceae), (Baessler and Klotz 2006), Myosotis arvensis (L.) Hill. (Boraginaceae), Viola tricolor L. (Violaceae) (Andreasen et al. 1996), Anchusa arvensis (L.) Bieb. (Boraginaceae), L. speculum-veneris L. (Campanulaceae) (Albrecht and Mattheis 1998), Nigella arvensis L. (Ranunculaceae), Ornithogalum umbellatum L. (Hyacinthaceae) (Dutoit et al. 2004), Anthemis arvensis L. (Asteraceae), and Silene conica L. (Caryophyllaceae)
(Sutcliffe and Kay 2000). In Europe, the number of weeds recognized as rare continues to grow, with the exception of species whose persistence dynamics have little reliance on biotic action for pollination (Sutcliffe and Kay 2000). Lists of declining species include many weeds, which are threatened because they depend on flower visitors for seed set (Motten 1986; Biesmeijer et al. 2006). Indeed, rare weed species have difficulties attracting insects and their interactions with pollinators are more fragile (Pontin et al. 2006). Thus, stability of weed-insect pollinator networks is essential to maintaining biodiversity in the arable landscapes.

Moreover, the risk of decline is greatest when pollinator mutualistic interaction is specialized (Gibson et al. 2006). For instance, species of the Caryophyllaceae family are often characterized by rigid mutualistic interactions that are initiated by Lepidoptera (Kephart 2006). This type of interaction is fragile, since many Lepidoptera and other pollinators depend on the plants in two ways: they require flowers with nectaries as a food source and certain host plants for oviposition and feeding of larval forms (Kremen et al. 2007; Nicholls and Altieri 2012; Benelli et al. 2014). Butterfly species frequently depend on restricted plant groups, often belonging to a single botanical family, a single genus or even a single species. A good example is the Old World swallowtail Papilio machaon L. (Lepidoptera: Papilionidae) which oviposits exclusively on Apiaceae (Wiklund 1981), as well as Macroglossum stellatarum L. which needs Galium spp. (Rubiaceae) as larval diet. On the other hand, in Nymphalidae, there is little specialization (e.g., the great-banded grayling, Brintesia circe (Fabr.)) as the pollinator-weed interaction is observed in many Graminaceae species. If certain host plants have poor invasiveness within the various ecosystems, this inevitably leads to a scant presence of the related butterfly species (Dennis et al. 2004). Interestingly, while generalist pollinators (e.g., bees) promote weedy species and potentially create risks for weed populations, the specificity between butterflies and their host plants hinders weeds, as the butterflies are specific in their need for hosts. Therefore, Hymenoptera pollinators may inadvertently promote weeds while butterflies do not, and the risk of butterfly-plant host co-extinction has already been reported in some parts of the world (Koh et al. 2004). Consequently, more specialized weed species involved in mutualistic relationships could constitute the most reliable ecological assessment parameters since they are species whose presence is threatened by the disruption of the agro-ecosystem's biodiversity (Bàrberi et al. 2010).

The frequency of rare weeds in arable land plant communities represents an indicator of their ecological sustainability (Benvenuti and Macchia 2003; Albrecht 2003; Gabriel and Tscharntke 2007). This is particularly true for insectpollinated species, since their presence presupposes a level of biodiversity that extends to the animal kingdom (Levin 1971; Holzschuh et al. 2006; Nicholls and Altieri 2012). 
Hyvönen and Huusela-Veistola (2008) propose some agrobiodiversity indicators based on the trophic networks between 25 common arable weeds and individual groups of farmland birds, pollinators (mainly wild bees), and insect pests. Interestingly, they note that, after high levels of agricultural intensity, the slowest recovery of values was for pollinators.

Overall, several rare weed-Lepidoptera visitors networks occur in arable lands (Jennersten 1988; Rundlöf and Smith 2006). For instance, (i) Geometridae (e.g., Euphyia biangulata Haworth) visiting Caryophyllaceae and (ii) Papilionidae (e.g., P. machaon) foraging on Apiaceae represent potential indicators of the biodiversity of arable lands (Novák and Severa 1980). Other butterflies, such as P. rapae, choose the same species both for pollinating and for oviposition. This exemplifies mutualism and parasitism simultaneously (Jones 1987) which may result in a "fitness conflict" for the organisms involved (Dufaÿ and Anstett 2003). Among Diptera, the widespread presence of Syrphidae (e.g., Eristalis arbustorum (L.)) has been considered as a good indicator of plant biodiversity (Hegland and Boeke 2006). Although they are able to successfully reproduce in a wide range of habitats, their presence has been frequently recorded in association with rare weed flowerings (e.g., G. segetum (L.) Fourr.). G. segetumSyrphidae interactions could, thus, be potential bio-indicators of the health of arable land.

\section{Agricultural practices affecting the stability of weed-insect pollinator networks}

Many intensive agricultural practices negatively affect vegetal and animal biodiversity. The ecological consequences of changes in the intensity of arable land management can be explored with the aid of biodiversity indicators based on species interactions (Suárez et al. 2001; Osinski et al. 2003).

\subsection{The spatiotemporal dynamic in agricultural landscapes: the importance of a heterogeneous mosaic}

The spatiotemporal arrangement of agricultural landscapes affects significantly both weed and insect pollinator communities and consequently interactions between them and stability of pollination networks. The diversity of weeds in arable fields increases with the complexity of the landscape (Gabriel et al. 2005; Pinke et al. 2009). Landscape complexity is often defined by the rapport between quantity of arable land and quantity of non-arable lands (natural and semi-natural habitats such as grasslands, set-aside fields, hedges, and forests). Landscape complexity increases with percentage of nonarable lands in the landscape (Gabriel et al. 2005). Consequently, landscape planning is crucial for biodiversity (Rookwood 1995; Grass et al. 2013). Increased habitat diversity, structural heterogeneity, and reduced patch disturbance can significantly promote species richness and genetic variability and reduce extinction rates of many species (Barbault 1995; Dover 1996; Potts et al. 2009; Bàrberi et al. 2010). Thus, weed management is a key factor in the sustainability of agriculture (Gerowitt 2003; Bengtsson et al. 2005; Hole et al. 2005). Concerning weed pollinators, to avoid excessive energy consumption for foraging flights, distances between nesting sites and food sources must not be excessive. For instance, bees are central place foragers and cannot relocate their nest once it has been established (Kevan and Baker 1983). Abundance and diversity of bees increase with the connectivity between favorable habitat patches (Banaszak 1992; Steffan-Dewenter 2003; Williams et al. 2010), increasing the stability of pollination services (Garibaldi et al. 2011). Thus, they cannot persist and assure an effective pollination service to plants in homogeneous environments where nesting sites are too distant from foraging resources (Kluser and Peduzzi 2007; Williams et al. 2010).

It is also very important to consider the effect of temporal arrangement (inter- and intra-annual variations) of arable landscapes on the weed communities and their pollinators. Crop rotation is an major determinant of seed density in soil (Cardina et al. 2002). Longer crop rotations, combined with less intensive tillage, increase the diversity of emerged and seedbank weed species (Murphy et al. 2006). In addition, attractive long-term flowering crops, such as alfalfa Medicago sativa L. (Fabaceae), could be integrated in crop rotations, to promote insect pollinators and their pollination services (Rollin et al. 2013). Indeed, alfalfa was the most evenly used flowering crop among bees in an intensive agricultural landscape. It performed better for wild bee groups compared to semi-natural herbaceous habitats during summer, even if only $30 \%$ of all wild bee genera reported were observed in alfalfa (Andrena, Halictus, Hoplosmia, Lasioglossum, Megachile, Melitta, Xylocopa) (Rollin et al. 2013). Moreover, annual mass flowering crops can change the floral resource availability in the landscape temporarily, which can transiently modify pollinator preferences and the stability of pollinator-wild flora networks, with functional consequences for the ecosystem (Tscharntke et al. 2012). For instance, the mass flowering of oilseed rape temporarily increases attractiveness of the crop and decreases pollination of the wild plant Primula veris L. by bees in adjacent natural areas (Holzschuh et al. 2011).

\subsection{The key role of untilled areas for weed-insect pollinator networks}

The spatiotemporal arrangement of arable lands should be complemented by untilled areas in the form of managed or natural conservation lands, or farm dams and scattered trees in fields, to ensure that insect-pollinated weeds are retained in the intensive agricultural landscape (Kremen et al. 2007; Lentini 
et al. 2012). Intensive agricultural practices have increased the loss of natural and semi-natural areas (e.g., permanent grasslands, set-aside areas, gardens, hedges, woods, filed margins), with a significant negative effect on insects pollinators (Duelli and Obrist 2003; Le Féon et al. 2010). Yet, these areas are essential habitats for insect pollinators providing both appropriate foraging and nesting resources (Steffan-Dewenter and Tscharntke 2001; Potts et al. 2003; Vulliamy et al. 2006; Öckinger and Smith 2007; Goulson 2010; Rollin et al. 2013; Requier et al. 2014). For instance, woods represent a fundamental reserve of suitable sites for the survival and reproduction of pollinators (Potts et al. 2006), especially if they are located in a mosaic pattern within an agricultural setting (Banaszak 1992). Other areas offer a suitable environment for soil-nesting bee pollinators and Lepidoptera species that require particular weeds on which to oviposit (Graves and Shapiro 2003). For example, cattle grazing can exert beneficial effects on weed-insect pollinator networks, by promoting open mosaic areas with richer and more temporally heterogeneous habitats (e.g., grasslands) (Vázquez and Simberloff 2003; Zamora et al. 2007).

The communities of weed-visiting insects can be enhanced by field margins, hedges (Marshall and Arnold 1995), other buffer zones (Ma et al. 2002), and set-aside fields (Corbet 1995; Steffan-Dewenter and Tscharntke 1997; Blaauw and Isaacs 2014). Weeds linked to mutualistic relations with pollinators can successfully grow in field margins. They provide suitable ecological niches for many pollinators. The introduction of wildflower strips favors a potentially stable community of cavity-nesting hymenoptera (Fabian et al. 2013), with particular reference to honey bees (Decourtye et al. 2010, 2011). But the efficiency of flowering areas managed for bees can be influenced by the presence of alternative flowers in the seminatural habitats close by (Henry et al. 2012; Blaauw and Isaacs 2014). Furthermore, it leads to an increase in Lepidoptera searching host plants for oviposition and nectar as a food source (Saarinen 2002). Hoverflies are also attracted by certain flowering strips, such as alyssum (Lobularia maritima (L.) Desv., Brassicaceae) (Nicholls and Altieri 2012). The use of native weeds within or around intensely farmed landscapes helps to safeguard pollinator biodiversity, particularly the specialized pollinators linked to specific weeds (Carvell et al. 2007). It also has further benefits, such as pest population reductions, protects soil and water quality by mitigating runoff and soil erosion, and enhances rural aesthetics (Wratten et al. 2012). Despite the benefit to pollinators feeding, the presence of agri-environmental schemes based on weeds poses a risk of insecticide exposure to bees foraging when the area is treated (Girolami et al. 2012; Botias et al. 2015). Therefore, the enhancement of floral resources for bees in agrosystems through the establishment of habitats containing flowering weeds must be accompanied by supplemental pesticide mitigation strategies.

\subsection{Reduce external inputs to increase biodiversity}

The decrease in some weeds may be due to the intensive use of external inputs (Marshall et al. 2003; Bretagnolle and Gaba 2015). This can be direct effects on weeds (e.g., herbicides, fertilizers) or indirect effects on their pollinators (e.g., insecticides). It is likely that the decline in pollinators is highly linked to weed decline (Kluser and Peduzzi 2007). Application of pesticides and inorganic fertilizers have considerably increased during the last few decades (Robinson and Sutherland 2002; Baessler and Klotz 2006) and cause significant modifications and decreases in the diversity of weed communities (Sutcliffe and Kay 2000; Hyvönen and Salonen 2002; Baessler and Klotz 2006; Storkey et al. 2009; Andreasen and Streibig 2011) and in weed seedbanks (Robinson and Sutherland 2002). However, herbicides affect species diversity and species composition more than nitrogen fertilization (Hyvönen and Salonen 2002). Nitrogen fertilizers promote nitrophilous species (e.g., Chenopodium album L. and S. media (L.) Vill.) and weed species with physiological shade tolerance (e.g., Poa annua L., S. media, and V. arvensis L.) because of enhancing the shading ability of crops (Andreasen and Streibig 2011). Moreover, herbicides significantly decrease weed density and plant height (Mavunganidze et al. 2014), while they are important factors for pollinator attractiveness. Insect visitors may show density-dependent preferences when different types of flowers are available within their environment, such as mass flowering crops (Rands and Whitney 2010). Even at low wildflower density compared to the mass flowering crop, insect pollinators can shift away from their preferred crop when wildflower density increases within filed margins. For instance, increasing tubular blossom density increases visit frequency by bumblebees and beetles (Hegland and Boeke 2006). Increasing number of flowers per plant (e.g., E. vulgare L.) can also promote bee attractiveness (Klinkhamer and Jong 1990).

Regarding insect pollinators of weeds, pesticides use in crops can be an additional source of chronic exposure for insect pollinators, due to the widespread contamination by pesticide residues of weeds growing in and near treated crops (Botias et al. 2015). Moreover, the herbicide resistance of some weed species (e.g., glyphosate) leads to increasing herbicide use in crops (Andreasen and Streibig 2011; Heap 2014; Labreuche et al. 2014; Fernandez et al. 2015) and thus increases the global risk of exposure for insect pollinators of weeds. The impact of agri-environmental schemes on insects is probably also an indirect result of the impact of the vegetation management (Kleijn et al. 2006). Field reduction of 
fertilizer and herbicide applications significantly enhance plant species diversity (Hyvönen and Salonen 2002) and can promote bees through the increase of flowering weeds adjacent to crop areas (Kleijn et al. 2006). Organic farming systems have significant positive effects on pollination networks. For instance in Germany, a higher bee diversity, flower cover, and diversity of flowering plants have been recorded in organic compared with conventional fields (Holzschuh et al. 2006). These findings were confirmed by further research, highlighting that landscapes in Germany that comprise higher proportions of organic crop fields support more bee species, at greater abundances in fallow strips. An increase in organic cropping in the surrounding landscape, from 5 to $20 \%$, enhanced the richness of bee species in fallow strips by $50 \%$, the density of solitary bees by $60 \%$, and bumblebee density by $150 \%$ (Holzschuh et al. 2008).

\subsection{No tillage: an efficient practice to associate with other environmental strategies}

Since 2000, weed management schemes have changed with an increase of crop areas not subjected to tillage. The main objective of conservation tillage is to minimize erosion and degradation of soils. It is a common practice in North and South America where in areas are characterized by intensive soil erosion (Holland 2004).

No tillage promotes weed communities, with an increase of both abundance and diversity of emerged and seedbank weeds (Cardina et al. 2002; Murphy et al. 2006; Labreuche et al. 2014). No tillage also changes the composition of the weed community, promoting annual grasses and perennial weeds with deeper plant roots (Labreuche et al. 2014). To nesting sites, numerous species of bees have their nests in the soil. Solitary mining bees (e.g., Andrena spp., Halictus spp., Lasioglossum spp.) directly excavate soil to construct their nests whereas bumblebees nest in pre-existing underground (e.g., old rodent nests) or aerial cavities or construct nests on the surface in tussocky grass (Michener 2007). It is important to adopt reduced, minimum, or non-tillage techniques, since less soil disturbance can favor the survival dynamics of these beneficial organisms (Kells and Goulson 2003; Nicholls and Altieri 2012). However, tillage should have a more significant effect on mining bees than on bumblebees whose nests are often located deeply below ground in hedgerow or woodland edges (Michener 2007).

However, no tillage is compensated by an increased use of herbicide, $30 \%$ of which is glyphosate (Labreuche et al. 2014). These practices promote the development of herbicide tolerance for many weed species (Labreuche et al. 2014) and consequently increase the risk of insecticide exposure for weed-insect pollinators (Botias et al. 2015). To conclude, even if no tillage has positive effects on weed communities and their pollinators, it must be supported by environmental schemes for the reduction of herbicides.

\section{Conclusions}

The preservation of biodiversity is an agronomic concern, since it involves the long-term enhancement of agricultural production (Bullock et al. 2007). This has led to a focus on the ecological interactions between the organisms involved in agricultural landscapes. The growing need to maintain and/or restore arable land biodiversity meant that we have focused on weed species that are becoming rare due to their dependence on pollinators (Paoletti 1995). Moreover, many insect pollinators are threatened by an increasing risk of extinction due to the gradual decrease in nectariferous plants that are food sources for adults, as well as by the decline of host plants that are essential for oviposition and larval development (e.g., butterflies species) (Kremen et al. 2007; Nicholls and Altieri 2012; Benelli et al. 2014).

In this review, we highlight the key role of insect pollinators, especially generalist species, in the pollination and the stability of weed communities in arable landscapes. Weedinsect pollinator interactions are modulated by flower traits, such as the flower's color, shape, and scent. These mutualistic interactions also depend on the quality of available pollen and nectar, particularly nectar composition in terms of sugars and amino acids, nectar viscosity, and secretion rate. We revealed that the stability of weed-insect pollinator interactions could be affected by some intensive agricultural practices (e.g., increasing external inputs, tillage, reduction of uncropped areas), with an increase of extinction risk for species with specialized interactions. Thus, it is important to work on alternative management strategies to combine crop production and biodiversity. For instance, reduced tillage in organic farming systems can preserve diversity of weeds in crops without compromising crop yield (Barberi et al. 2014).

Finally, we believe that the potential of rare weed-insect visitor networks we have proposed as bio-indicators of arable lands could be useful for a preliminary assessment of the sustainability of agronomic management. In particular, (i) the Geometridae (e.g., E. biangulata) and Bombyliidae species visiting Caryophyllaceae, (ii) the Papilionidae (e.g., P. machaon) foraging on Apiaceae, and (iii) the Syrphidae (e.g., E. arbustorum) visiting rare Asteraceae (e.g., G. segetum) could represent potential indicators of the biodiversity of arable lands. We therefore encourage research on this issue, highlighting the need for further data to confirm our hypotheses. Further knowledge in this area could also help to 
build up an agenda to restore ecologically damaged arable lands.

Acknowledgements We would like to thank Giulia Giunti for her assistance during manuscript preparation. Giovanni Benelli is supported by PROINNOVA CUP B15E11001510005. Funds were also provided by the Italian Ministry of Education, University and Research (MIUR). Funders had no role in the study design, data collection and analysis, decision to publish, or preparation of the manuscript.

Open Access This article is distributed under the terms of the Creative Commons Attribution 4.0 International License (http:// creativecommons.org/licenses/by/4.0/), which permits unrestricted use, distribution, and reproduction in any medium, provided you give appropriate credit to the original author(s) and the source, provide a link to the Creative Commons license, and indicate if changes were made.

\section{References}

Aarssen LW (2000) Why are most selfers annuals? A new hypothesis for the fitness benefit of selfing. Oikos 89:606-612. doi:10.1034/j. 1600-0706.2000.890321.x

Adler LS (2000) The ecological significance of toxic nectar. Oikos 91: $409-420$

Aigner PA (2001) Optimality modeling and fitness trade-offs: when should plants become pollinator specialists? Oikos 95:177-184. doi:10.1034/j.1600-0706.2001.950121.x

Albrecht H (2003) Suitability of arable weeds as indicator organisms to evaluate species conservation effects of management in agricultural ecosystems. Agric Ecosyst Environ 98:201-211. doi:10.1016/ S0167-8809(03)00081-1

Albrecht H, Mattheis A (1998) The effects of organic and integrated farming on rare arable weeds on the Forschungsverbund Agrarökosysteme München (FAM) research station in southern Bavaria. Biol Conserv 86:347-356. doi:10.1016/S0006-3207(98) 00028-7

Alm J, Ohnmeiss TE, Lanza J, Vriesenga L (1990) Preference of cabbage white butterflies and honey bees for nectar that contains amino acids. Oecologia 84:53-57. doi:10.1007/BF00665594

Andersson S (2008) Pollinator and nonpollinator selection on ray morphology in Leucanthemum vulgare (oxeye daisy, Asteraceae). Am J Bot 95:1072-1078. doi:10.3732/ajb.0800087

Andreasen C, Streibig JC (2011) Evaluation of changes in weed flora in arable fields of Nordic countries - based on Danish long-term surveys. Weed Res 51:214-226

Andreasen C, Stryhn H, Streibig JC (1996) Decline of the flora in Danish arable fields. J Appl Ecol 33:619-626. doi:10.2307/2404990

Arak A, Enquist M (1993) Hidden preferences and the evolution of signals. Philos Trans R Soc Lond B Biol Sci 340:207-213. doi:10. 1098/rstb.1993.0059

Arathi HS, Kelly JK (2004) Corolla morphology facilitates both autogamy and bumblebee pollination in Mimulus guttatus. Int J Plant Sci 165:1039-1045. doi:10.1086/423876

Armbruster WS (2001) Evolution of floral form: electrostatic forces, pollination, and adaptive compromise. New Phytol 152:181-183. doi: 10.1046/j.0028-646X.2001.00268.x

Baessler C, Klotz S (2006) Effects of changes in agricultural land-use on landscape structure and arable weed vegetation over the last 50 years. Agric Ecosyst Environ 115:43-50. doi:10.1016/j.agee.2005.12.007

Baker HG, Baker I (1983) Floral nectar sugar constituents in relation to pollinator type. Handb Exp Pollinat Biol 117:141
Banaszak J (1992) Strategy for conservation of wild bees in an agricultural landscape. Agric Ecosyst Environ 40:179-192. doi:10.1016/ 0167-8809(92)90091-O

Barbault R (1995) Biodiversity dynamics: from population and community ecology approaches to a landscape ecology point of view. Landsc Urban Plan 31:89-98. doi:10.1016/0169-2046(94)01038-A

Bàrberi P, Burgio G, Dinelli G et al (2010) Functional biodiversity in the agricultural landscape: relationships between weeds and arthropod fauna. Weed Res 50:388-401. doi:10.1111/j.1365-3180.2010. 00798.x

Barberi P, Aendekerk R, Antichi D, et al. (2014) Reduced tillage and cover crops in organic arable systems preserve weed diversity without jeopardising crop yield. In: Proceedings of the 4th ISOFAR Scientific Conference. Rahmann G \& Aksoy U (Eds.), Istanbul, Turkey, pp 765-768

Barbier E (1986) La Pollinisation des cultures: pourquoi?Comment. Chez l'auteur, Le Pontet, France

Bascompte J, Jordano P, Olesen JM (2006) Asymmetric coevolutionary networks facilitate biodiversity maintenance. Science 312:431-433. doi:10.1126/science. 1123412

Bawa KS (1995) Pollination, seed dispersal and diversification of angiosperms. Trends Ecol Evol 10:311-312. doi:10.1016/S01695347(00)89116-8

Beattie A (1971) Pollination mechanisms in Viola. New Phytol 70:343360

Beattie AJ, Turnbull C, Knox RB, Williams EG (1984) Ant inhibition of pollen function: a possible reason why ant pollination is rare. Am J Bot 71:421-426. doi:10.2307/2443499

Benelli G, Benvenuti S, Desneux N, Canale A (2014) Cephalaria transsylvanica-based flower strips as potential food source for bees during dry periods in European Mediterranean Basin countries. PLoS ONE 9:e93153. doi:10.1371/journal.pone.0093153

Bengtsson J, Ahnström J, Weibull A-C (2005) The effects of organic agriculture on biodiversity and abundance: a meta-analysis. J Appl Ecol 42:261-269. doi:10.1111/j.1365-2664.2005.01005.x

Benton TG, Bryant DM, Cole L, Crick HQP (2002) Linking agricultural practice to insect and bird populations: a historical study over three decades. J Appl Ecol 39:673-687. doi:10.1046/j.1365-2664.2002. 00745.x

Benvenuti S (2004) Weed dynamics in the Mediterranean urban ecosystem: ecology, biodiversity and management. Weed Res 44:341-354

Benvenuti S, Macchia M (2003) Weed community dynamics in perennial medicinal crops of organic agricultural systems. Adv Hortic Sci 17(4):207-214

Bertazzini M, Medrzycki P, Bortolotti L et al (2010) Amino acid content and nectar choice by forager honeybees (Apis mellifera L.). Amino Acids 39:315-318. doi:10.1007/s00726-010-0474-x

Biesmeijer JC, Roberts SPM, Reemer M et al (2006) Parallel declines in pollinators and insect-pollinated plants in Britain and the Netherlands. Science 313:351-354. doi:10.1126/science.1127863

Blaauw BR, Isaacs R (2014) Larger patches of diverse floral resources increase insect pollinator density, diversity, and their pollination of native wildflowers. Basic Appl Ecol 15:701-711. doi:10.1016/j. baae.2014.10.001

Blair AC, Wolfe LM (2004) The evolution of an invasive plant: an experimental study with Silene latifolia. Ecology 85:3035-3042. doi: $10.1890 / 04-0341$

Blionis GJ, Vokou D (2001) Pollination ecology of Campanula species on Mt Olympos, Greece. Ecography 24:287-297. doi:10.1111/j. 1600-0587.2001.tb00201.x

Bloch D, Werdenberg N, Erhardt A (2006) Pollination crisis in the butterfly-pollinated wild carnation Dianthus carthusianorum? New Phytol 169:699-706

Blüthgen N, Menzel F, Blüthgen N (2006) Measuring specialization in species interaction networks. BMC Ecol 6:9. doi:10.1186/14726785-6-9 
Bosch J, Retana J, Cerdá X (1997) Flowering phenology, floral traits and pollinator composition in a herbaceous Mediterranean plant community. Oecologia 109:583-591. doi:10.1007/s004420050120

Botias C, David A, Horwood J et al (2015) Neonicotinoid residues in wildflowers, a potential route of chronic exposure for bees. Environ Sci Technol (web). doi:10.1021/acs.est.5b03459

Brenner DM, Baltensperger DD, Kulakow PA, et al. (2000) Genetic resources and breeding of Amaranthus. In: Janick J (ed) Plant Breeding Reviews. John Wiley \& Sons, Inc., pp 227-285

Bretagnolle V, Gaba S (2015) Weeds for bees? A review. Agron Sustain Dev 35:891-909. doi:10.1007/s13593-015-0302-5

Brian AD (1957) Differences in the flowers visited by four species of bumble bees and their causes. J Anim Ecol 26:71-98. doi:10.2307/ 1782

Brückmann SV, Krauss J, Steffan-Dewenter I (2010) Butterfly and plant specialists suffer from reduced connectivity in fragmented landscapes. J Appl Ecol 47:799-809. doi:10.1111/j.1365-2664.2010. 01828.x

Bullock JM, Pywell RF, Walker KJ (2007) Long-term enhancement of agricultural production by restoration of biodiversity. J Appl Ecol 44:6-12. doi:10.1111/j.1365-2664.2006.01252.x

Burger H, Dötterl S, Häberlein CM et al (2011) An arthropod deterrent attracts specialised bees to their host plants. Oecologia 168:727736. doi:10.1007/s00442-011-2136-4

Campbell DR, Bischoff M (2013) Selection for a floral trait is not mediated by pollen receipt even though seed set in the population is pollen-limited. Funct Ecol 27:1117-1125. doi:10.1111/1365-2435. 12131

Canale A, Loni A (2010) Insects visiting olive flowers (Olea europaea L.) in a Tuscan olive grove. Redia 93:95-98

Canale A, Benelli G, Benvenuti S (2014) First record of insect pollinators visiting Muscari comosum (L.) Miller (Liliaceae-Hyacinthaceae), an ancient Mediterranean food plant. Plant Biosyst - Int J Deal Asp Plant Biol 148:889-894. doi:10.1080/11263504.2013.863810

Canale A, Benvenuti S, Raspi A, Benelli G (2015) Insect pollinators of the late winter flowering Rhamnus alaternus L., a candidate for honeybee-friendly scrubland spots in intensively managed agricultural areas. Plant Biosyst - Int J Deal Asp Plant Biol:1-5. doi: 10. 1080/11263504.2014.993742

Cardina J, Herms CP, Doohan DJ (2002) Crop rotation and tillage system effects on weed seedbanks. Weed Sci 50:448-460. doi:10.1614/ 0043-1745(2002)050[0448:CRATSE]2.0.CO;2

Carvell C, Meek WR, Pywell RF et al (2007) Comparing the efficacy of agri-environment schemes to enhance bumble bee abundance and diversity on arable field margins. J Appl Ecol 44:29-40. doi:10. 1111/j.1365-2664.2006.01249.x

Chamberlain DE, Fuller RJ, Bunce RGH et al (2000) Changes in the abundance of farmland birds in relation to the timing of agricultural intensification in England and Wales. J Appl Ecol 37:771-788

Chancellor RJ (1977) A preliminary survey of arable weeds in Britain. Weed Res 17:283-287. doi:10.1111/j.1365-3180.1977.tb00479.x

Chancellor RJ (1986) Decline of Arable weed seeds during 20 years in soil under grass and the periodicity of seedling emergence after cultivation. J Appl Ecol 23:631-637. doi:10.2307/2404041

Clegg MT, Durbin ML (2000) Flower color variation: a model for the experimental study of evolution. Proc Natl Acad Sci 97:7016-7023. doi:10.1073/pnas.97.13.7016

Conner AJ, Glare TR, Nap J-P (2003) The release of genetically modified crops into the environment. Plant J 33:19-46. doi:10.1046/j.09607412.2002.001607.x

Cooley AM, Carvallo G, Willis JH (2008) Is floral diversification associated with pollinator divergence? Flower shape, flower colour and pollinator preference in Chilean mimulus. Ann Bot 101:641-650. doi:10.1093/aob/mcn014

Corbet SA (1995) Ecological costs and benefits of set-aside in Britain: insects, plants and succession. Agric Ecosyst Environ 53:201-217
Corbet SA (2003) Nectar sugar content: estimating standing crop and sécrétion rate in the field. Apidologie 34:1-10

Costea M, Weaver SE, Tardif FJ (2004) The biology of Canadian weeds. 130. Amaranthus retroflexus L., A. powellii S. Watson and A. hybridus L. Can J Plant Sci 84:631-668. doi:10.4141/P02-183

Culley TM, Weller SG, Sakai AK (2002) The evolution of wind pollination in angiosperms. Trends Ecol Evol 17:361-369. doi:10.1016/ S0169-5347(02)02540-5

Dafni A (1996) Autumnal and winter pollination adaptations under Mediterranean conditions. Bocconea 5:171-181

Davis SL, Delph LF (2005) Prior selfing and gynomonoecy in Silene noctiflora L. (Caryophyllaceae): opportunities for enhanced outcrossing and reproductive assurance. Int J Plant Sci 166:475480. doi: $10.1086 / 428630$

De Jong TJ (2000) From pollen dynamics to adaptive dynamics. Plant Species Biol 15:31-41. doi:10.1046/j.1442-1984.2000.00028.x

De Jong TJ, Waser NM, Klinkhamer PGL (1993) Geitonogamy: the neglected side of selfing. Trends Ecol Evol 8:321-325. doi:10. 1016/0169-5347(93)90239-L

Decourtye A, Mader E, Desneux N (2010) Landscape enhancement of floral resources for honey bees in agro-ecosystems. Apidologie 41: 264-277. doi:10.1051/apido/2010024

Decourtye A, Alaux C, Odoux J-F, et al. (2011) Why enhancement of floral resources in agro-ecosystems benefit honeybees and beekeepers? In: Ecosystems Biodiversity. InTech

Delaplane KS, Mayer DF (2000) Crop pollination by bees. CABI, New York

Dennis RLH, Hodgson JG, Grenyer R et al (2004) Host plants and butterfly biology. Do host-plant strategies drive butterfly status? Ecol Entomol 29:12-26. doi:10.1111/j.1365-2311.2004.00572.x

Desneux N, Decourtye A, Delpuech J-M (2007) The sublethal effects of pesticides on beneficial arthropods. Annu Rev Entomol 52:81-106. doi:10.1146/annurev.ento.52.110405.091440

Di Pasquale C, Jacobi CM (1998) Dynamics of pollination: a model of insect-mediated pollen transfer in self-incompatible plants. Ecol Model 109:25-34. doi:10.1016/S0304-3800(97)00223-8

Dicks LV, Corbet SA, Pywell RF (2002) Compartmentalization in plantinsect flower visitor webs. J Anim Ecol 71:32-43. doi:10.1046/j. 0021-8790.2001.00572.x

Dötterl S, Milchreit K, Schäffler I (2011) Behavioural plasticity and sex differences in host finding of a specialized bee species. J Comp Physiol A 197:1119-1126. doi:10.1007/s00359-011-0673-2

Dover JW (1996) Factors affecting the distribution of satyrid butterflies on arable farmland. J Appl Ecol 33:723-734. doi:10.2307/2404943

Duelli P, Obrist MK (2003) Regional biodiversity in an agricultural landscape: the contribution of seminatural habitat islands. Basic Appl Ecol 4:129-138. doi:10.1078/1439-1791-00140

Dufaÿ M, Anstett M-C (2003) Conflicts between plants and pollinators that reproduce within inflorescences: evolutionary variations on a theme. Oikos 100:3-14. doi:10.1034/j.1600-0706.2003.12053.x

Dukas R (2008) Evolutionary biology of insect learning. Annu Rev Entomol 53:145-160. doi:10.1146/annurev.ento.53.103106.093343

Dupont YL, Hansen DM, Rasmussen JT, Olesen JM (2004) Evolutionary changes in nectar sugar composition associated with switches between bird and insect pollination: the Canarian bird-flower element revisited. Funct Ecol 18:670-676. doi:10.1111/j.0269-8463.2004. 00891.x

Dutoit T, Buisson E, Roche P, Alard D (2004) Land use history and botanical changes in the calcareous hillsides of Upper-Normandy (north-western France): new implications for their conservation management. Biol Conserv 115:1-19. doi:10.1016/S00063207(03)00089-2

Elzinga JA, Atlan A, Biere A et al (2007) Time after time: flowering phenology and biotic interactions. Trends Ecol Evol 22:432-439. doi:10.1016/j.tree.2007.05.006 
Fabian Y, Sandau N, Bruggisser OT et al (2013) The importance of landscape and spatial structure for hymenopteran-based food webs in an agro-ecosystem. J Anim Ecol 82:1203-1214. doi:10.1111/ 1365-2656.12103

Fenner M (1998) The phenology of growth and reproduction in plants. Perspect Plant Ecol Evol Syst 1:78-91. doi:10.1078/1433-831900053

Fenster CB, Armbruster WS, Wilson P et al (2004) Pollination syndromes and floral specialization. Annu Rev Ecol Evol Syst 35:375-403

Fernandez P, Gauvrit C, Barro F, et al. (2015) First case of glyphosate resistance in France. Agron Sustain Dev 1-8. doi: 10.1007/s13593015-0322-1

Flynn DFB, Gogol-Prokurat M, Nogeire T et al (2009) Loss of functional diversity under land use intensification across multiple taxa. Ecol Lett 12:22-33. doi:10.1111/j.1461-0248.2008.01255.x

Fried G, Norton LR, Reboud X (2008) Environmental and management factors determining weed species composition and diversity in France. Agric Ecosyst Environ 128:68-76. doi:10.1016/j.agee. 2008.05.003

Gabriel D, Tscharntke T (2007) Insect pollinated plants benefit from organic farming. Agric Ecosyst Environ 118:43-48. doi:10.1016/j. agee.2006.04.005

Gabriel D, Thies C, Tscharntke T (2005) Local diversity of arable weeds increases with landscape complexity. Perspect Plant Ecol Evol Syst 7:85-93. doi:10.1016/j.ppees.2005.04.001

Galen C (1983) The effects of nectar thieving ants on seedset in floral scent morphs of Polemonium viscosum. Oikos 41:245-249. doi:10. $2307 / 3544271$

Gange AC, Smith AK (2005) Arbuscular mycorrhizal fungi influence visitation rates of pollinating insects. Ecol Entomol 30:600-606. doi:10.1111/j.0307-6946.2005.00732.x

Gardener MC, Gillman MP (2001) The effects of soil fertilizer on amino acids in the floral nectar of corncockle, Agrostemma githago (Caryophyllaceae). Oikos 92:101-106. doi:10.1034/j.1600-0706. 2001.920112.x

Gardener MC, Gillman MP (2002) The taste of nectar - a neglected area of pollination ecology. Oikos 98:552-557. doi:10.1034/j.16000706.2002.980322.x

Garibaldi LA, Steffan-Dewenter I, Kremen C et al (2011) Stability of pollination services decreases with isolation from natural areas despite honey bee visits. Ecol Lett 14:1062-1072. doi:10.1111/j.14610248.2011.01669.x

Gegear RJ, Manson JS, Thomson JD (2007) Ecological context influences pollinator deterrence by alkaloids in floral nectar. Ecol Lett 10:375-382. doi:10.1111/j.1461-0248.2007.01027.x

Gerowitt B (2003) Development and control of weeds in arable farming systems. Agric Ecosyst Environ 98:247-254. doi:10.1016/S01678809(03)00084-7

Gibbs PE, Talavera S (2001) Breeding system studies with three species of Anagallis (Primulaceae): self-incompatibility and reduced female fertility in A. monelli L. Ann Bot 88:139-144. doi:10.1006/anbo. 2001.1439

Gibson RH, Nelson IL, Hopkins GW et al (2006) Pollinator webs, plant communities and the conservation of rare plants: arable weeds as a case study. J Appl Ecol 43:246-257. doi:10.1111/j.1365-2664.2006. 01130.x

Gilbert FS (1985) Ecomorphological relationships in Hoverflies (Diptera, Syrphidae). Proc R Soc Lond B Biol Sci 224:91-105. doi:10.1098/ rspb.1985.0023

Gilbert F, Jervis M (1998) Functional, evolutionary and ecological aspects of feeding-related mouthpart specializations in parasitoid flies. Biol J Linn Soc 63:495-535. doi:10.1006/bijl.1997.0208

Girolami V, Marzaro M, Vivan L et al (2012) Fatal powdering of bees in flight with particulates of neonicotinoids seed coating and humidity implication. J Appl Entomol 136:17-26. doi:10.1111/j.1439-0418. 2011.01648.x
Giurfa M, Amots D, Neal PR (1999) Floral symmetry and its role in plant-pollinator systems. Int J Plant Sci 160:S41-S50. doi:10. $1086 / 314214$

Goulson D (2000) Are insects flower constant because they use search images to find flowers? Oikos 88:547-552. doi:10.1034/j.16000706.2000.880311.x

Goulson D (2010) Bumblebees: behaviour, ecology, and conservation. pp

Graham L, Jones KN (1996) Resource partitioning and per-flower foraging efficiency in two bumble bee species. Am Midl Nat 136:401406. doi: $10.2307 / 2426743$

Grass I, Berens DG, Peter F, Farwig N (2013) Additive effects of exotic plant abundance and land-use intensity on plant-pollinator interactions. Oecologia 173:913-923. doi:10.1007/s00442-013-2688-6

Graves SD, Shapiro AM (2003) Exotics as host plants of the California butterfly fauna. Biol Conserv 110:413-433. doi:10.1016/S00063207(02)00233-1

Gu H, Cao A, Walter GH (2001) Host selection and utilisation of Sonchus oleraceus (Asteraceae) by Helicoverpa armigera (Lepidoptera: Noctuidae): a genetic analysis. Ann Appl Biol 138: 293-299

Heap I (2014) Herbicide resistant weeds. In: Pimentel D, Peshin R (eds) Integrated pest management. Springer, Netherlands, pp 281-301

Hegland SJ, Boeke L (2006) Relationships between the density and diversity of floral resources and flower visitor activity in a temperate grassland community. Ecol Entomol 31:532-538. doi:10.1111/j. 1365-2311.2006.00812.x

Henry M, Fröchen M, Maillet-Mezeray J et al (2012) Spatial autocorrelation in honeybee foraging activity reveals optimal focus scale for predicting agro-environmental scheme efficiency. Ecol Model 225: 103-114. doi:10.1016/j.ecolmodel.2011.11.015

Hermanutz L (1991) Outcrossing in the weed, Solanum ptycanthum (Solanaceae): a comparison of agrestal and ruderal populations. Am J Bot 78:638-646. doi:10.2307/2445085

Herrera CM (1995) Floral biology, microclimate, and pollination by ectothermic bees in an early-blooming herb. Ecology 76:218-228. doi: $10.2307 / 1940644$

Hoffmann F (2005) Biodiversity and pollination. Thesis, University of Groningen

Hole DG, Perkins AJ, Wilson JD et al (2005) Does organic farming benefit biodiversity? Biol Conserv 122:113-130. doi:10.1016/j. biocon.2004.07.018

Holland JM (2004) The environmental consequences of adopting conservation tillage in Europe: reviewing the evidence. Agric Ecosyst Environ 103:1-25. doi:10.1016/j.agee.2003.12.018

Holsinger KE (1991) Mass-action models of plant mating systems: the evolutionary stability of mixed mating systems. Am Nat 138:606622

Holzschuh A, Steffan-Dewenter I, Kleijn D, Tscharntke T (2006) Diversity of flower-visiting bees in cereal fields: effects of farming system, landscape composition and regional context. J Appl Ecol 44:41-49. doi:10.1111/j.1365-2664.2006.01259.x

Holzschuh A, Steffan-Dewenter I, Tscharntke T (2008) Agricultural landscapes with organic crops support higher pollinator diversity. Oikos 117:354-361. doi:10.1111/j.2007.0030-1299.16303.x

Holzschuh A, Dormann CF, Tscharntke T, Steffan-Dewenter I (2011) Expansion of mass-flowering crops leads to transient pollinator dilution and reduced wild plant pollination. Proc R Soc B Biol Sci 278:3444-3451. doi:10.1098/rspb.2011.0268

Howlett BG, Walker MK, McCallum JA, Teulon DAJ (2009) Small flower-visiting arthropods in New Zealand pak choi field. N Z Plant Prot 62:86-91

Huang S-Q (2006) Debates enrich our understanding of pollination biology. Trends Ecol Evol 21:233-234

Hyvönen T, Huusela-Veistola E (2008) Arable weeds as indicators of agricultural intensity - a case study from Finland. Biol Conserv 141:2857-2864. doi:10.1016/j.biocon.2008.08.022 
Hyvönen T, Salonen J (2002) Weed species diversity and community composition in cropping practices at two intensity levels - a sixyear experiment. Plant Ecol 159:73-81. doi:10.1023/ A: 1015580722191

Ishii HS, Harder LD (2006) The size of individual Delphinium flowers and the opportunity for geitonogamous pollination. Funct Ecol 20: 1115-1123. doi:10.1111/j.1365-2435.2006.01181.x

Jennersten O (1984) Flower visitation and pollination efficiency of some North European butterflies. Oecologia 63:80-89. doi:10.1007/ BF00379789

Jennersten O (1988) Pollination in Dianthus deltoides (Caryophyllaceae): effects of habitat fragmentation on visitation and seed set. Conserv Biol 2:359-366

Johnson SD, Dafni A (1998) Response of bee-flies to the shape and pattern of model flowers: implications for floral evolution in a Mediterranean herb. Funct Ecol 12:289-297. doi:10.1046/j.13652435.1998.00175.x

Johnson SD, Steiner KE (2000) Generalization versus specialization in plant pollination systems. Trends Ecol Evol 15:140-143. doi:10. 1016/S0169-5347(99)01811-X

Jones RE (1987) Behavioural evolution in the cabbage butterfly (Pieris rapae). Oecologia 72:69-76. doi:10.1007/BF00385047

Jordano P (1987) Patterns of mutualistic interactions in pollination and seed dispersal: connectance, dependence asymmetries, and coevolution. Am Nat 129:657-677

Jordano P, Bascompte J, Olesen JM (2003) Invariant properties in coevolutionary networks of plant-animal interactions. Ecol Lett 6:69-81. doi:10.1046/j.1461-0248.2003.00403.x

Junker R, Chung AYC, Blüthgen N (2006) Interaction between flowers, ants and pollinators: additional evidence for floral repellence against ants. Ecol Res 22:665-670. doi:10.1007/s11284-006-0306-3

Jürgens A (2006) Comparative floral morphometrics in day-flowering, night-flowering and self-pollinated Caryophylloideae (Agrostemma, Dianthus, Saponaria, Silene, and Vaccaria). Plant Syst Evol 257: 233-250. doi:10.1007/s00606-005-0379-4

Kalisz S, Vogler D, Fails B et al (1999) The mechanism of delayed selfing in Collinsia verna (Scrophulariaceae). Am J Bot 86:1239-1247

Katzourakis A, Purvis A, Azmeh S et al (2001) Macroevolution of hoverflies (Diptera: Syrphidae): the effect of using higher-level taxa in studies of biodiversity, and correlates of species richness. J Evol Biol 14:219-227. doi:10.1046/j.1420-9101.2001.00278.x

Kawaano S, Odaki M, Yamaoka R, Oda-Tanabe M, Takeuchi M, Kawano N (1995) Pollination biology of Oenothera (Onagraceae): the interplay between floral UV-absorbancy patterns and floral volatiles as signals to nocturnal insects. Plant Spec Biol 10:31-38

Kay QON (1971) Biological flora of the British Isles: Anthemis cotula L. J Ecol 59:637-648

Kay QON, Lack AJ, Bamber FC, Davies CR (1984) Differences between sexes in floral morphology, nectar production and insect visits in a dioecious species, Silene dioica. New Phytol 98:515-529. doi:10. 1111/j.1469-8137.1984.tb04145.x

Kells AR, Goulson D (2003) Preferred nesting sites of bumblebee queens (Hymenoptera: Apidae) in agroecosystems in the UK. Biol Conserv 109:165-174. doi:10.1016/S0006-3207(02)00131-3

Kephart S (2006) Pollination mutualisms in Caryophyllaceae. New Phytol 169:637-640. doi:10.1111/j.1469-8137.2006.01656.x

Kephart S, Theiss K ( 2004) Pollinator-mediated isolation in sympatric milkweeds (Asclepias): do floral morphology and insect behavior influence species boundaries? New Phytologist 161:265-277

Kevan PG, Baker HG (1983) Insects as flower visitors and pollinators. Annu Rev Entomol 28:407-453. doi:10.1146/annurev.en.28. 010183.002203

Kim W, Gilet T, Bush JWM (2011) Optimal concentrations in nectar feeding. Proc Natl Acad Sci 108:16618-16621. doi:10.1073/pnas. 1108642108
Kirk WDJ, Howes FN (2012) Plants for bees: a guide to the plants that benefit the bees of the British Isles. International Bee Research Association

Kleijn D, Sutherland WJ (2003) How effective are European agri-environment schemes in conserving and promoting biodiversity? J Appl Ecol 40:947-969. doi:10.1111/j.1365-2664.2003.00868.x

Kleijn D, Baquero RA, Clough Y et al (2006) Mixed biodiversity benefits of agri-environment schemes in five European countries. Ecol Lett 9:243-254. doi:10.1111/j.1461-0248.2005.00869.x

Klinkhamer PGL, de Jong TJ (1990) Effects of plant size, plant density and sex differential nectar reward on pollinator visitation in the protandrous Echium vulgare (Boraginaceae). Oikos 57:399-405. doi: $10.2307 / 3565970$

Kluser S, Peduzzi P (2007) Global pollinator decline: a literature review

Koh LP, Sodhi NS, Brook BW (2004) Co-extinctions of tropical butterflies and their hostplants. Biotropica 36:272-274. doi:10.1111/j. 1744-7429.2004.tb00319.x

Koul P, Koul AK, Hamal IA (1989) Reproductive biology of wild and cultivated carrot (Daucus carota L.). New Phytol 112:437-443. doi: 10.1111/j.1469-8137.1989.tb00335.x

Kremen C, Williams NM, Aizen MA et al (2007) Pollination and other ecosystem services produced by mobile organisms: a conceptual framework for the effects of land-use change. Ecol Lett 10:299 314. doi:10.1111/j.1461-0248.2007.01018.x

Krenn HW, Plant JD, Szucsich NU (2005) Mouthparts of flower-visiting insects. Arthropod Struct Dev 34:1-40. doi:10.1016/j.asd.2004.10. 002

Labreuche J, Laurent F, Roger-Estrade J (2014) Faut-il travailler le sol? Acquis et innovations pour une agriculture durable. Editions Quae

Lack AJ (1982) Competition for pollinators in the ecology of Centaurea scabiosa L. and Centaurea nigra L. II. Observations on nectar production. New Phytologist 91: 309-320.

Lamborn E, Ollerton J (2000) Experimental assessment of the functional morphology of inflorescences of Daucus carota (Apiaceae): testing the "fly catcher effect.". Funct Ecol 14:445-454. doi:10.1046/j. 1365-2435.2000.00440.x

Larson BMH, Kevan PG, Inouye DW (2001) Flies and flowers: taxonomic diversity of anthophiles and pollinators. Can Entomol 133: 439-465. doi:10.4039/Ent133439-4

Larson DL, Royer RA, Royer MR (2006) Insect visitation and pollen deposition in an invaded prairie plant community. Biol Conserv 130:148-159. doi:10.1016/j.biocon.2005.12.009

Le Féon V, Schermann-Legionnet A, Delettre Y et al (2010) Intensification of agriculture, landscape composition and wild bee communities: a large scale study in four European countries. Agric Ecosyst Environ 137:143-150. doi:10.1016/j.agee.2010.01.015

Leiss KA, Klinkhamer PGL (2005) Genotype by environment interactions in the nectar production of Echium vulgare. Funct Ecol 19: 454-459. doi:10.1111/j.1365-2435.2005.00986.x

Lentini PE, Martin TG, Gibbons P et al (2012) Supporting wild pollinators in a temperate agricultural landscape: maintaining mosaics of natural features and production. Biol Conserv 149:84-92. doi:10. 1016/j.biocon.2012.02.004

Levin DA (1971) Competition for pollinator service: a stimulus for the evolution of the autogamy. Evolution 26:668-674

Levin DA, Anderson WW (1970) Competition for pollinators between simultaneously flowering species. Am Nat 104:455-467

Lunau K (2006) Stamens and mimic stamens as components of floral colour patterns. Bot Jahrb 127:13-41. doi:10.1127/0006-8152/ 2006/0127-0013

Lundqvist A (1994) The self-incompatibility system in Ranunculus repens (Ranunculaceae). Hereditas 120:151-157. doi:10.1111/j. 1601-5223.1994.00151.x

Ma M, Tarmi S, Helenius J (2002) Revisiting the species-area relationship in a semi-natural habitat: floral richness in agricultural buffer 
zones in Finland. Agric Ecosyst Environ 89:137-148. doi:10.1016/ S0167-8809(01)00325-5

Mader E, Shepherd M, Vaughan M et al (2011) Attracting native pollinators: protecting North America's bees and butterflies: the Xerces Society guide. Storey Pub, North Adams

Maloof JE, Inouye DW (2000) Are nectar robbers cheaters or mutualists? Ecology 81:2651-2661. doi:10.1890/0012-9658(2000) 081[2651:ANRCOM]2.0.CO;2

Marshall EJP, Arnold GM (1995) Factors affecting field weed and field margin flora on a farm in Essex, UK. Landsc Urban Plan 31:205216. doi:10.1016/0169-2046(94)01047-C

Marshall EJP, Brown VK, Boatman ND et al (2003) The role of weeds in supporting biological diversity within crop fields. Weed Res 43:7789. doi:10.1046/j.1365-3180.2003.00326.x

Matson PA, Parton WJ, Power AG, Swift MJ (1997) Agricultural intensification and ecosystem properties. Science 277:504-509. doi:10. 1126/science. 277.5325 .504

Mavunganidze Z, Madakadze IC, Nyamangara J, Mafongoya P (2014) The impact of tillage system and herbicides on weed density, diversity and yield of cotton (Gossipium hirsutum L.) and maize (Zea mays L.) under the smallholder sector. Crop Prot 58:25-32. doi: 10.1016/j.cropro.2013.12.024

Meiss H, Munier-Jolain N, Henriot F, Caneill J (2008) Effects of biomass, age and functional traits on regrowth of arable weeds after cutting. J Plant Dis Prot 21:493-499

Memmott J (1999) The structure of a plant-pollinator food web. Ecol Lett 2:276-280. doi:10.1046/j.1461-0248.1999.00087.x

Menzel R, Shmida A (1993) The ecology of flower colours and the natural colour vision of Insect pollinators: the Israeli flora as a study case. Biol Rev 68:81-120. doi:10.1111/j.1469-185X.1993.tb00732. $\mathrm{x}$

Michener CD (2007) The bees of the world, 2nd revised edition. Johns Hopkins University Press, Baltimore

Motten AF (1986) Pollination ecology of the spring wildflower community of a temperate deciduous forest. Ecol Monogr 56:21-42. doi:10. $2307 / 2937269$

Motten AF, Antonovics J (1992) Determinants of outcrossing rate in a predominantly self-fertilizing weed, Datura stramonium (Solanaceae). Am J Bot 79:419-427. doi:10.2307/2445154

Motten AF, Stone JL (2000) Heritability of stigma position and the effect of stigma-anther separation on outcrossing in a predominantly selffertilizing weed, Datura stramonium (Solanaceae). Am J Bot 87: 339-347

Murphy SD, Clements DR, Belaoussoff S et al (2006) Promotion of weed species diversity and reduction of weed seedbanks with conservation tillage and crop rotation. Weed Sci 54:69-77. doi:10.1614/WS04-125R1.1

Nakano C, Washitani I (2003) Variability and specialization of plantpollinator systems in a northern maritime grassland. Ecol Res 18: 221-246. doi:10.1046/j.1440-1703.2003.00550.x

Naug D, Arathi HS (2007) Sensory bias of honeybees for exaggerated signals and its implications for the evolution of floral displays. Biol Lett 3:635-637

Newman DA, Thomson JD (2005) Interactions among nectar robbing, floral herbivory, and ant protection in Linaria vulgaris. Oikos 110: 497-506. doi:10.1111/j.0030-1299.2005.13885.x

Nicholls CI, Altieri MA (2012) Plant biodiversity enhances bees and other insect pollinators in agroecosystems. A review. Agron Sustain Dev 33:257-274. doi:10.1007/s13593-012-0092-y

Nicolson SW, de Veer L, Köhler A, Pirk CWW (2013) Honeybees prefer warmer nectar and less viscous nectar, regardless of sugar concentration. Proc R Soc Lond B Biol Sci 280:20131597. doi:10.1098/ rspb.2013.1597

Nilson LA (1998) Deep flowers for long tongues. Trends Ecol Evol 13: $259-260$
Novák I, Severa F (1980) Impariamo a conoscere le farfalle. Istituto geografico De Agostini, Novara

Nyman Y (1993) The pollen-collecting hairs of campanula (Campanulaceae). II. Function and adaptive significance in relation to pollination. Am J Bot 80:1437-1443. doi:10.2307/2445673

Öckinger E, Smith HG (2007) Semi-natural grasslands as population sources for pollinating insects in agricultural landscapes. J Appl Ecol 44:50-59. doi:10.1111/j.1365-2664.2006.01250.x

Odoux J-F, Feuillet D, Aupinel P et al (2012) Territorial biodiversity and consequences on physico-chemical characteristics of pollen collected by honey bee colonies. Apidologie 43:561-575. doi:10.1007/ s13592-012-0125-1

Oerke E-C (2006) Crop losses to pests. J Agric Sci 144:31-43. doi:10. $1017 / \mathrm{S} 0021859605005708$

Osinski E, Kantelhardt J, Heissenhuber A (2003) Economic perspectives of using indicators. Agric Ecosyst Environ 98:477-482. doi:10. 1016/S0167-8809(03)00106-3

Paoletti MG (1995) Biodiversity, traditional landscapes and agroecosystem management. Landsc Urban Plan 31:117-128. doi: 10.1016/0169-2046(94)01040-F

Pesson P (1984) Transport du pollen par les animaux: zoogamie. In: Pollinisation et productions végétales, Editions Quae. Pesson P, Louveaux J, Paris, pp 97-139

Pesson P, Louveaux J (1984) Pollinisation et productions végétales. Quae

Petanidou T, Lamborn E (2005) A land for flowers and bees: studying pollination ecology in Mediterranean communities. Plant Biosyst Int J Deal Asp Plant Biol 139:279-294. doi:10.1080/ 11263500500333941

Petanidou T, Vokou D (1993) Pollination ecology of Labiatae in a phryganic (East Mediterranean) ecosystem. Am J Bot 80:892-899. doi: $10.2307 / 2445509$

Petanidou T, Van Laere A, Ellis WN, Smets E (2006) What shapes amino acid and sugar composition in Mediterranean floral nectars? Oikos 115:155-169. doi:10.1111/j.2006.0030-1299.14487.x

Pinke G, Pál R, Botta-Dukát Z, Chytrý M (2009) Weed vegetation and its conservation value in three management systems of Hungarian winter cereals on base-rich soils. Weed Res 49:544-551. doi:10.1111/j. 1365-3180.2009.00730.x

Pisciotta S, Raspi A, Sajeva M (2011) First records of pollinators of two co-occurring Mediterranean Apocynaceae. Plant Biosyst - Int J Deal Asp Plant Biol 145:141-149. doi:10.1080/11263504.2010.540779

Pontin DR, Wade MR, Kehrli P, Wratten SD (2006) Attractiveness of single and multiple species flower patches to beneficial insects in agroecosystems. Ann Appl Biol 148:39-47. doi:10.1111/j.17447348.2005.00037.x

Potts SG, Vulliamy B, Dafni A et al (2003) Linking bees and flowers: how do floral communities structure pollinator communities? Ecology 84:2628-2642

Potts SG, Petanidou T, Roberts S et al (2006) Plant-pollinator biodiversity and pollination services in a complex Mediterranean landscape. Biol Conserv 129:519-529. doi:10.1016/j.biocon.2005.11.019

Potts SG, Woodcock BA, Roberts SPM et al (2009) Enhancing pollinator biodiversity in intensive grasslands. J Appl Ecol 46:369-379. doi: 10.1111/j.1365-2664.2009.01609.x

Preston C, Powles SB (2002) Evolution of herbicide resistance in weeds: initial frequency of target site-based resistance to acetolactate synthase-inhibiting herbicides in Lolium rigidum. Heredity 88:813. doi:10.1038/sj.hdy. 6800004

Pyke GH (1991) What does it cost a plant to produce floral nectar? Nature 350:58-59. doi: $10.1038 / 350058 \mathrm{a} 0$

Rands SA, Whitney HM (2010) Effects of pollinator density-dependent preferences on field margin visitations in the midst of agricultural monocultures: a modelling approach. Ecol Model 221:1310-1316. doi:10.1016/j.ecolmodel.2010.01.014 
Ranta E, Lundberg H (1980) Resource partitioning in bumblebees: the significance of differences in proboscis length. Oikos 35:298-302. doi: $10.2307 / 3544643$

Rasheed S, Harder L (1997) Economic motivation for plant species preferences of pollen-collecting bumble bees. Ecol Entomol 22:209 219. doi:10.1046/j.1365-2311.1997.t01-1-00059.x

Requier F, Odoux J-F, Tamic T et al (2014) Honey bee diet in intensive farmland habitats reveals an unexpectedly high flower richness and a major role of weeds. Ecol Appl 25:881-890. doi:10.1890/14-1011. 1

Rhoades DF, Bergdahl JC (1981) Adaptive significance of toxic nectar. Am Nat 117:798-803. doi:10.2307/2460766

Ricciardelli d'Arbore G, Intoppa F ( 2000) Fiori e api. Bologna: Calderini

Robinson RA, Sutherland WJ (2002) Post-war changes in arable farming and biodiversity in Great Britain. J Appl Ecol 39:157-176. doi:10. 1046/j.1365-2664.2002.00695.x

Rodger JG, van Kleunen M, Johnson SD (2010) Does specialized pollination impede plant invasions? Int J Plant Sci 171:382-391. doi:10. $1086 / 651226$

Rollin O (2013) Etude multi-echelle du patron de diversite des abeilles et utilisation des ressources fleuries dans un agrosystem intensif. Thèse de Doctorat, Université d'Avignon et des Pays de Vaucluse

Rollin O, Bretagnolle V, Decourtye A et al (2013) Differences of floral resource use between honey bees and wild bees in an intensive farming system. Agric Ecosyst Environ 179:78-86. doi:10.1016/j. agee.2013.07.007

Rollin O, Bretagnolle V, Fortel L et al (2015) Habitat, spatial and temporal drivers of diversity patterns in a wild bee assemblage. Biodivers Conserv 24:1195-1214. doi:10.1007/s10531-014-0852-x

Rookwood P (1995) Landscape planning for biodiversity. Landsc Urban Plan 31:379-385. doi:10.1016/0169-2046(94)01064-F

Roubik DW (1982) The ecological impact of nectar-robbing bees and pollinating hummingbirds on a tropical shrub. Ecology 63:354 360. doi:10.2307/1938953

Rundlöf M, Smith HG (2006) The effect of organic farming on butterfly diversity depends on landscape context. J Appl Ecol 43:1121-1127. doi:10.1111/j.1365-2664.2006.01233.x

Rust RW (1979) Pollination of impatiens capensis: pollinators and nectar robbers. J Kans Entomol Soc 52:297-308

Rusterholz H-P, Erhardt A (2000) Can nectar properties explain sexspecific flower preferences in the Adonis Blue butterfly Lysandra bellargus? Ecol Entomol 25:81-90. doi:10.1046/j.1365-2311.2000. 00233.x

Saarinen K (2002) A comparison of butterfly communities along field margins under traditional and intensive management in SE Finland. Agric Ecosyst Environ 90:59-65. doi:10.1016/S0167-8809(01) 00168-2

Sakai S (2002) A review of brood-site pollination mutualism: plants providing breeding sites for their pollinators. J Plant Res 115:161-168. doi:10.1007/s 102650200021

Sampson DR (1967) Frequency and distribution of self-incompatibility alleles in Raphanus raphanistrum. Genetics 56:241-251

Sauvion N, Calatayud P-A, Thiéry D, Marion-Poll F (2013) Interactions insectes-plantes. Editions Quae

Scheper J, Holzschuh A, Kuussaari M et al (2013) Environmental factors driving the effectiveness of European agri-environmental measures in mitigating pollinator loss - a meta-analysis. Ecol Lett 16:912920. doi:10.1111/ele.12128

Schuhmacher H, Hoffmann H (1982) Zur Funktion der Mundwerkzeuge von Schwebfliegen bei der Nahrungsaufnahme (Diptera: Syrphidae). Entomol Gen 7:327-342

Scott PE, Buchmann SL, O'rourke MK (1993) Evidence for mutualism between a flower-piercing carpenter bee and ocotillo: use of pollen and nectar by nesting bees. Ecol Entomol 18:234-240. doi:10.1111/ j.1365-2311.1993.tb01095.x
Shapiro AM (2002) The Californian urban butterfly fauna is dependent on exotic plants. Divers Distrib 8:31-40

Shuttleworth A, Johnson SD (2008) Bimodal pollination by wasps and beetles in the African milkweed Xysmalobium undulatum. Biotropica 40:568-574. doi:10.1111/j.1744-7429.2008.00418.x

Sotherton NW (1998) Land use changes and the decline of farmland wildlife: an appraisal of the set-aside approach. Biol Conserv 83: 259-268. doi:10.1016/S0006-3207(97)00082-7

Southwick EE (1984) Photosynthate allocation to floral nectar: a neglected energy investment. Ecology 65:1775-1779. doi:10. 2307/1937773

Stanton ML, Snow AA, Handel SN, Bereczky J (1989) The impact of a flower-color polymorphism on mating patterns in experimental populations of wild radish (Raphanus raphanistrum L.). Evolution 43: 335-346. doi:10.2307/2409211

Steffan-Dewenter I (2003) Importance of habitat area and landscape context for species richness of bees and wasps in fragmented orchard meadows. Conserv Biol 17:1036-1044. doi:10.1046/j.1523-1739. 2003.01575.x

Steffan-Dewenter I, Tscharntke T (1997) Early succession of butterfly and plant communities on set-aside fields. Oecologia 109:294 302. doi: $10.1007 / \mathrm{s} 004420050087$

Steffan-Dewenter I, Tscharntke T (2001) Succession of bee communities on fallows. Ecography 24:83-93. doi:10.1034/j.1600-0587.2001. 240110.x

Stevens JP, Kay QON (1989) Heredity - abstract of article: the number, dominance relationships and frequencies of self-incompatibility alleles in a natural population of Sinapis arvensis L. in South Wales. Heredity 62:199-205

Storkey J, Moss SR, Cussans JW (2009) Using assembly theory to explain changes in a weed flora in response to agricultural intensification. Weed Sci 58:39-46. doi:10.1614/WS-09-096.1

Stout JC, Allen JA, Goulson D (2000) Nectar robbing, forager efficiency and seed set: bumblebees foraging on the self incompatible plant Linaria vulgaris (Scrophulariaceae). Acta Oecol 21:277-283. doi: 10.1016/S1146-609X(00)01085-7

Suárez SA, Fuente EB et al (2001) Weed community as an indicator of summer crop yield and site quality. Agron J 93:524-530. doi:10. 2134/agronj2001.933524x

Sutcliffe OL, Kay QON (2000) Changes in the arable flora of central southern England since the 1960s. Biol Conserv 93:1-8. doi:10. 1016/S0006-3207(99)00119-6

Sutherland S (2004) What makes a weed a weed: life history traits of native and exotic plants in the USA. Oecologia 141:24-39. doi:10. 1007/s00442-004-1628-x

Tepedino VJ, Parker FD (1982) Interspecific differences in the relative importance of pollen and nectar to bee species foraging on sunflowers. Environ Entomol 11:246-250

Theis N (2006) Fragrance of Canada thistle (Cirsium arvense) attracts both floral herbivores and pollinators. J Chem Ecol 32:917-927. doi:10.1007/s10886-006-9051-x

Theis N, Manuel L, Raguso RA (2007) The challenge of attracting pollinators while evading floral herbivores: patterns of fragrance emission in Cirsium arvense and Cirsium repandum (Asteraceae). Int $\mathrm{J}$ Plant Sci 168:587-601. doi:10.1086/513481

Thien LB (1980) Patterns of pollination in the primitive angiosperms. Biotropica 12:1-13. doi:10.2307/2387768

Thomas SG, Franklin-Tong VE (2004) Self-incompatibility triggers programmed cell death in Papaver pollen. Nature 429:305-309. doi:10. 1038/nature02540

Thomas JA, Telfer MG, Roy DB et al (2004) Comparative losses of British butterflies, birds, and plants and the global extinction crisis. Science 303:1879-1881. doi:10.1126/science.1095046

Thorp RW (1979) Structural, behavioral and physiological adaptations of bees (Apoidea) for collecting pollen. Ann Mo Bot Gard 66:788-812 
Torres C, Mimosa M, Ferreira MF, Galetto L (2013) Reproductive strategies of Datura ferox, an abundant invasive weed in agroecosystems from central Argentina. Flora - Morphol Distrib Funct Ecol Plants 208:253-258. doi:10.1016/j.flora.2013.03.008

Tscharntke T, Klein AM, Kruess A et al (2005) Landscape perspectives on agricultural intensification and biodiversity - ecosystem service management. Ecol Lett 8:857-874. doi:10.1111/j.1461-0248.2005. 00782.x

Tscharntke T, Tylianakis JM, Rand TA et al (2012) Landscape moderation of biodiversity patterns and processes - eight hypotheses. Biol Rev 87:661-685. doi:10.1111/j.1469-185X.2011.00216.x

Tylianakis JM, Klein A-M, Tscharntke T (2005) Spatiotemporal variation in the diversity of Hymenoptera across a tropical habitat gradient. Ecology 86:3296-3302. doi:10.1890/05-0371

Vaissière BE, Vinson SB (1994) Pollen morphology and its effect on pollen collection by honey bees, Apis mellifera L. (Hymenoptera: Apidae), with special reference to upland cotton, Gossypium hirsutum L. (Malvaceae). Grana 33:128-138. doi:10.1080/ 00173139409428989

Van der Cingel NAVD (2001) An atlas of orchid pollination: european orchids. CRC Press, London

Van Schie CC, Haring MA, Schuurink RC (2006) Regulation of terpenoid and benzenoid production in flowers. Curr Opin Plant Biol 9: 203-208. doi:10.1016/j.pbi.2006.01.001

Vázquez DP, Simberloff D (2003) Changes in interaction biodiversity induced by an introduced ungulate. Ecol Lett 6:1077-1083. doi: 10.1046/j.1461-0248.2003.00534.x

Vázquez DP, Blüthgen N, Cagnolo L, Chacoff NP (2009) Uniting pattern and process in plant-animal mutualistic networks: a review. Ann Bot 103:1445-1457. doi:10.1093/aob/mcp057

Verkleij JAC, de Boer AM, Lugtenborg TF (1980) On the ecogenetics of Stellaria media (L.) Vill. and Stellaria pallida (Dum.) pire from abandoned arable field. Oecologia 46:354-359. doi:10.1007/ BF00346264

Vulliamy B, Potts SG, Willmer PG (2006) The effects of cattle grazing on plant-pollinator communities in a fragmented Mediterranean landscape. Oikos 114:529-543. doi:10.1111/j.2006.0030-1299.14004.x
Waser NM, Ollerton J (2006) Plant-pollinator interactions: from specialization to generalization. University of Chicago Press

Westrich P (1989) Die Wildbienen Baden-Württemburgs: Spezieller Teil - Die Gattungen und Arten. Eugen Ulmer, Germany

Westwood JH, Tominaga T, Weller SC (1997) Characterization and breakdown of self-incompatibility in field bindweed (Convolvulus arvensis L.). J Hered 88:459-465

Wiklund C (1981) Generalist vs. specialist oviposition behaviour in Papilio machaon (Lepidoptera) and functional aspects on the hierarchy of oviposition preferences. Oikos 36:163-170. doi:10.2307/ 3544441

Williams NM, Crone EE, Roulston TH et al (2010) Ecological and lifehistory traits predict bee species responses to environmental disturbances. Biol Conserv 143:2280-2291. doi:10.1016/j.biocon.2010. 03.024

Wratten SD, Gillespie M, Decourtye A et al (2012) Pollinator habitat enhancement: benefits to other ecosystem services. Agric Ecosyst Environ 159:112-122. doi:10.1016/j.agee.2012.06.020

Wright GA, Schiestl FP (2009) The evolution of floral scent: the influence of olfactory learning by insect pollinators on the honest signalling of floral rewards. Funct Ecol 23:841-851. doi:10.1111/j.1365-2435. 2009.01627.x

Yoshioka Y, Horisaki A, Kobayashi K et al (2005) Intraspecific variation in the ultraviolet colour proportion of flowers in Brassica rapa $\mathrm{L}$. Plant Breed 124:551-556. doi:10.1111/j.1439-0523.2005.01132.x

Young HJ (2002) Diurnal and nocturnal pollination of Silene alba (Caryophyllaceae). Am J Bot 89:433-440. doi:10.3732/ajb.89.3. 433

Zamora J, Verdú JR, Galante E (2007) Species richness in Mediterranean agroecosystems: spatial and temporal analysis for biodiversity conservation. Biol Conserv 134:113-121. doi:10.1016/j.biocon.2006. 08.011

Zimmerman CA (1977) A comparison of breeding systems and seed physiologies in three species of Portulaca L. Ecology 58:860-868. doi: $10.2307 / 1936221$ 